\title{
Molecular signatures of T-cell inhibition in HIV-1 infection
}

\author{
Marie Larsson ${ }^{1 *}$, Esaki M Shankar² ${ }^{2 *}$ Karlhans F Che ${ }^{3}$, Alireza Saeidi², Rada Ellegård', Muttiah Barathan², \\ Vijayakumar Velu ${ }^{5}$ and Adeeba Kamarulzaman ${ }^{4}$
}

\begin{abstract}
Cellular immune responses play a crucial role in the control of viral replication in HIV-infected individuals. However, the virus succeeds in exploiting the immune system to its advantage and therefore, the host ultimately fails to control the virus leading to development of terminal AIDS. The virus adopts numerous evasion mechanisms to hijack the host immune system. We and others recently described the expression of inhibitory molecules on T cells as a contributing factor for suboptimal T-cell responses in HIV infection both in vitro and in vivo. The expression of these molecules that negatively impacts the normal functions of the host immune armory and the underlying signaling pathways associated with their enhanced expression need to be discussed. Targets to restrain the expression of these molecular markers of immune inhibition is likely to contribute to development of therapeutic interventions that augment the functionality of host immune cells leading to improved immune control of HIV infection. In this review, we focus on the functions of inhibitory molecules that are expressed or secreted following HIV infection such as BTLA, CTLA-4, CD160, IDO, KLRG1, LAG-3, LILRB1, PD-1, TRAIL, TIM-3, and regulatory cytokines, and highlight their significance in immune inhibition. We also highlight the ensemble of transcriptional factors such as BATF, BLIMP-1/PRDM1, FoxP3, DTX1 and molecular pathways that facilitate the recruitment and differentiation of suppressor T cells in response to HIV infection.
\end{abstract}

Keywords: BLIMP-1, CTLA-4, FoxP3, HIV-1, T-cell inhibition, LAG-3, PD-1, TIM-3, 2B4, CD160

\section{Review}

\section{Introduction}

Functional senescence of virus-specific $\mathrm{T}$ cells and progressive loss of naïve $\mathrm{CD}_{4}^{+}$and $\mathrm{CD} 8^{+} \mathrm{T}$ cells are features of HIV infection [1]. One effect HIV infection has, is to facilitate the expansion of suppressor T cells, which compromises HIV-specific $\mathrm{CD} 4^{+}$and $\mathrm{CD} 8^{+} \mathrm{T}$ cell responses by acting in a contact-dependent manner [2-5]. HIV infection can alter the survival rates and regenerative capacity of T cells [6]. A recent study also showed that HIV-infected $\mathrm{T}$ cells serve as migratory vehicles for viral dissemination [7] and therefore once infected may not contribute to viral clearance. Importantly, the impairment of effector T-cell immune functions in HIV infected individuals is reportedly

\footnotetext{
* Correspondence: marie.larsson@liu.se; shivamsarvam@gmail.com ${ }^{1}$ Molecular Virology, Department of Clinical and Experimental Medicine, Linköping University, 58185 Linköping, Sweden

${ }^{2}$ Tropical Infectious Disease Research and Education Center (TIDREC), Department of Medical Microbiology, Faculty of Medicine, University of Malaya, 50603 Lembah Pantai, Kuala Lumpur, Malaysia

Full list of author information is available at the end of the article
}

multifactorial [8], and upregulation of negative costimulatory and secretory factors and impaired cytokine production in HIV-specific $\mathrm{T}$ cells and other immune cells is believed to facilitate rapid disease progression and eventual systemic immune dysfunction $[9,10]$. Hence, the expression of inhibitory molecules on $\mathrm{T}$ cells has been proposed as a contributing factor for the suboptimal T-cell responses seen in HIV infection [2-6].

\section{Unraveling the complexity of T-cell costimulation}

The first step of HIV-1 transmission is mucosal exposure and Langerhans cells lining the genital mucosa, constitute a front-line defense against invading virus $[11,12]$. These dendritic cells (DCs) pick up HIV-1 from mucosal sites, and migrate to peripheral lymph nodes to activate HIVspecific naïve $\mathrm{T}$ cells. During migration the $\mathrm{DC}$ changes its phenotype and increases the expression of maturation markers, e.g. CD83, MHC class I and II, costimulatory molecules, and lymph node homing molecules, e.g. CCR7 (CD197). These events are critical for efficient antigen

\section{Biomed Central}


presentation, downstream signaling, and T-cell activation [12]. The $\mathrm{T}$ cells play a key role in cell-mediated immune responses, and their activation is multifaceted and requires distinct signals. The first signal occurs when the TCR recognizes the antigenic peptide bound to MHC molecules on APCs. The second signal, the costimulatory signal, can either be positive or negative, the former necessary for achieving full $\mathrm{T}$ cell activation and initiation of effective immunity and the latter for the establishment and maintenance of peripheral tolerance, and abortive T-cell responses [13]. A balance between positive and negative costimulatory pathways is required to sustain a normal protective response and these pathways are therefore attractive therapeutic targets for chronic diseases associated with immune suppression. The surface receptor CD28 is the primary costimulatory receptor for initial T-cell expansion and survival and the positive costimulatory signals provided by CD28 lead to dramatic increase in IL-2 secretion and promote clustering of TCRs, which potentiate TCR signaling [14]. CD28 binds to B7-1 (CD80) and B7-2 (CD86), expressed exclusively on professional APCs, and this enhances $\mathrm{T}$-cell proliferation by increasing the transcription of IL-2 and Bcl-xL [14]. Several other positive costimulatory molecules besides B7-1 and B7-2 exist that contribute to promote $\mathrm{T}$ cell functions and include inducible T-cell costimulator (ICOS: CD278), OX40 (CD134), 4-1BB (CD137), and CD40. In addition to the costimulatory molecules that promote $\mathrm{T}$-cell activation other molecules exist that instead, regulate and inhibit Tcell activation. Herein, we review the role of inhibitory molecules that are expressed on cells or secreted following HIV-1 infection, and focus on their significance in HIVassociated immune inhibition. Our recent findings showed that HIV-1 exposed DCs gave rise to increased expression of inhibitory molecules on expanded T cells (Figure 1) and that these $\mathrm{T}$ cells had the ability to act in a contactdependent manner on $\mathrm{T}$ cells present in their vicinity and suppressed their immune activation [2-4] (Figure 1). We also highlight the ensemble of repression factors and molecular pathways that facilitate the recruitment and differentiation of exhausted $\mathrm{T}$ cells in response to HIV-1 infection. The nature of the ensuing immune response depends on the initial stimuli and the binding amplitude of TCR-MHC-peptide complex formed during a given event of antigen presentation and subsequent engagement of positive or negative costimulatory molecules to their cognate receptors/ligands [15]. Chronic HIV infection reportedly induces expression of suppressor/inhibitory molecules that generate key negative signals that downregulate the ensuing $\mathrm{T}$-cell responses.

\section{Negative costimulatory molecules}

a) $P D-1$

PD-1 (CD279) is a 50-55 kD glycoprotein that belongs to the CD28/B7 Ig superfamily. PD-1 expression can be induced on $\mathrm{CD}^{+}$and $\mathrm{CD}^{+} \mathrm{T}$ cells, natural killer cells

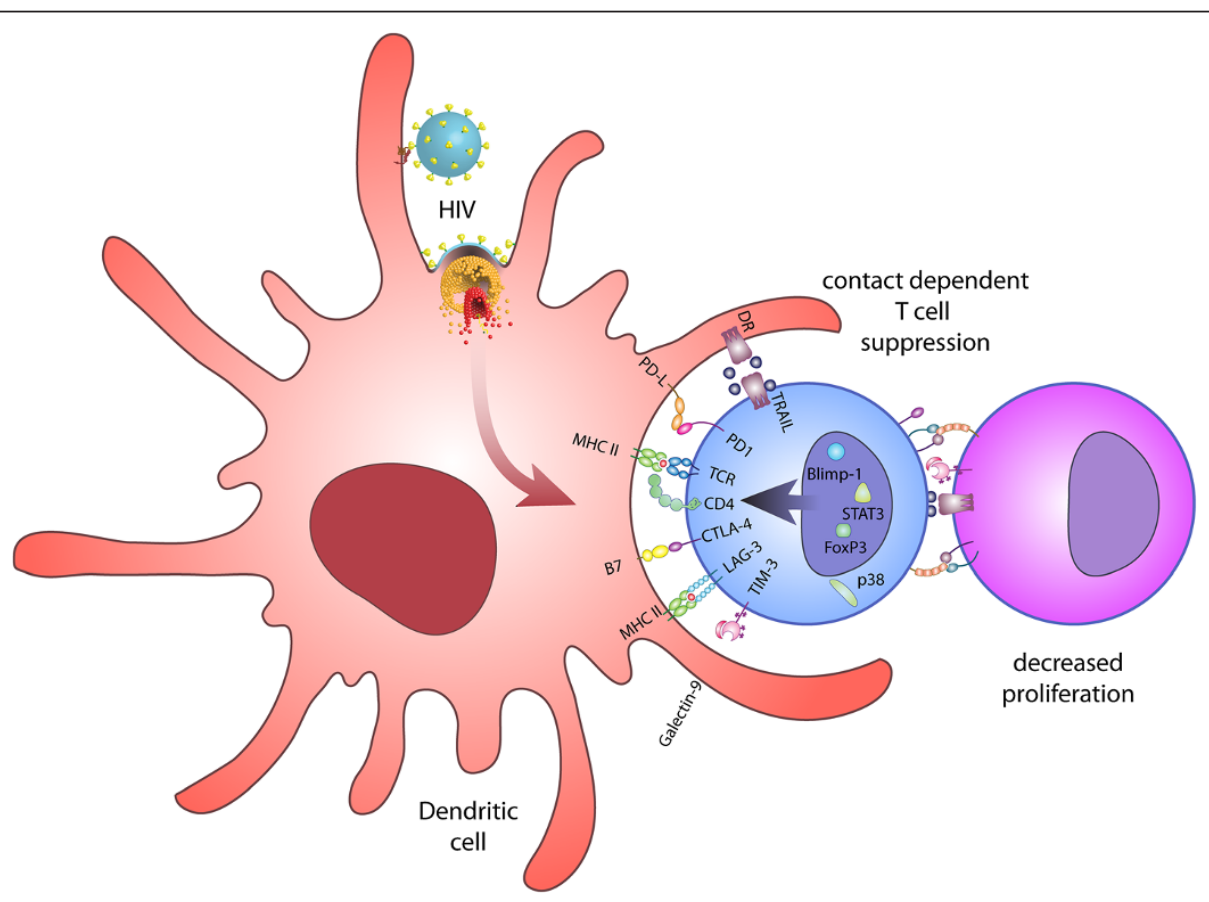

Figure 1 Infection with HIV facilitates the upregulation of inhibitory molecules in T cells. HIV-1 modulates host DCs to increase expression of numerous inhibitory molecules on expanded T cells. The expanded T cells are suppressor T cells [4] that act on other T cells present in the near vicinity in a contact-dependent manner [4], transforming them into suppressor cells and so contributing to eventual T-cell inhibition [3-5]. 
(NK cells), T cells, B cells, and monocytes when these cells are activated $[16,17]$. The PD-1/PD-L pathway leads to the transduction of a negative immunoregulatory signal that antagonizes the TCR-CD28-mediated activation of phosphatidylinositol 3-kinase (PI3K), which reduce Akt phosphorylation and glucose metabolism resulting in inhibition of T-cell activation [18,19] (Figure 2). PD-L2 (B7-DC;CD273) and PD-L1 (B7-H1;CD274) are PD-1 ligands. PD-L2 expression is inducible on DCs and macrophages, whereas PD-L1 expression is constitutive on both professional and non-professional APCs [16,17,20,21]. Signaling via PD-1 occurs only when this receptor is engaged at the same time as TCR, which is in accordance with other CD28 family members. The cytoplasmic domain of PD-1 contains two tyrosine signaling motifs and both are phosphorylated following receptor engagement [18]. Phosphorylation of the second tyrosine, an immunoreceptor tyrosine-based inhibitory motif (ITSM), recruits SHP-2 and SHP-1 to the PD-1 cytoplasmic domain [18]. This initiates dephosphorylation of TCR proximal signaling molecules (e.g. ZAP70, PKC $\theta$, and $\mathrm{CD} 3 \zeta$ ), leading to attenuation of the TCR/CD28 signaling cascade [18].

Accumulating lines of evidence suggest that the PD1-PD-L1 pathway protects the vascular system from severe $\mathrm{CD}^{+} \mathrm{T}$ cell-mediated pathology during early systemic murine lymphocytic choriomeningitis virus (LCMV) infection. However, the association of PD-1 pathway with cytotoxic $\mathrm{T}$ lymphocyte (CTL) inhibition has opened up investigations on its potential negative role in HIV infection [4]. It has been shown that PD-1 expression is elevated on SIV-specific $\mathrm{CD}^{+} \mathrm{T}$ cells and in vivo blockade of the $\mathrm{PD}-1-\mathrm{PD}-\mathrm{L}$ pathway in vivo leads to increased T-cell proliferation, effector cytokine production, SIV-specific B-cell responses, and prolonged survival [19-22]. $\mathrm{CD}^{+} \mathrm{T}$ cells in HIV-infected individuals are reportedly dysfunctional with reduced proliferative capacity and effector functions [23]. In agreement with this notion, others showed that HIV disease severity i.e. viral load and declining $\mathrm{CD} 4^{+} \mathrm{T}$-cell counts, correlated with level of both PD-1 expression on HIV-specific CD8 ${ }^{+} \mathrm{T}$ cells and percentage of cells expressing $\mathrm{PD}-1$, providing a marker on $\mathrm{CD}^{+} \mathrm{T}$ cells that correlates with disease severity [23]. In addition, PD-1 expression on HIV-specific $\mathrm{CD}^{+} \mathrm{T}$ cells was markedly reduced in patients on ART, consistent with the notion that high antigen load drives PD-1 expression and functional exhaustion [23,24]. Importantly, HIV-exposed DCs induce T-cell inhibition via PD-1/cytotoxic Tlymphocyte antigen-4 (CTLA-4) signaling [6]. HIV exposure also leads to PD-L1 upregulation and B7-1/B7-2, and CD40 downregulation on myeloid DCs and this impairs DC functions, which correlates with disease progression in chronic HIV infection [25].

We and others have recently proposed that the PD-1 pathway could be manipulated for use in the treatment of persistent viral infections (PVIs), especially HIV-1 infection $[5,21]$. However, there is evidence suggesting that this pathway protects the vascular system from severe $C D 8^{+} \mathrm{T}$

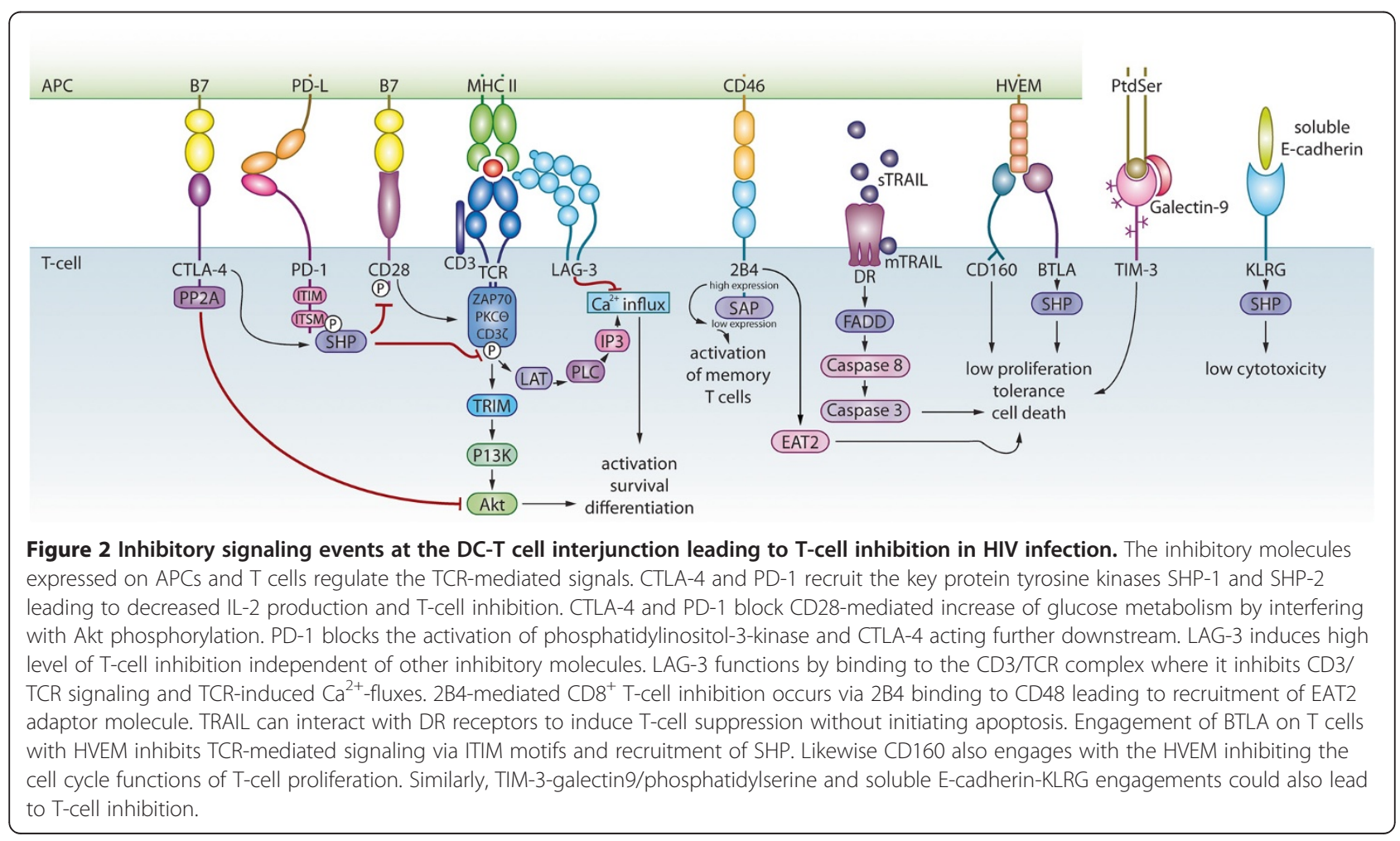


cell-mediated pathology during early systemic murine LCMV infection, indicating that immunopathological side effects might arise when interfering with the PD-1 pathway $[19,20,26]$. Accumulating evidence shows that HIVand SIV-specific CTLs express high levels of PD-1, which contributes to the impaired proliferative $\mathrm{T}$-cell responses $[21,27,28]$. The control of viral load in HIV and SIV infections correlates with reduced PD-1 expression on virusspecific CTLs, and PD-1 blockade results in enhanced HIV- or SIV-specific CTL proliferative responses [21,27,28]. Recent findings have extended the observation that $\mathrm{T}$ cells primed by HIV-pulsed DCs lead to expansion of T cells expressing multiple inhibitory molecules to include T-cell Ig mucin-containing domain-3 (TIM-3), lymphocyte activation gene-3 (LAG-3), and CTLA-4 besides PD-1 [2,4]. Further, HIV-specific $\mathrm{CD}^{+}{ }^{+}$and $\mathrm{CD} 4^{+} \mathrm{T}$ cells that coexpress high levels of PD-1 and CD160 are more functionally impaired than cells with lower expression of these markers [29]. Hence, it is important to investigate the association of PD-1 with T-cell inhibition, especially in regards to the ability of virus-specific CTLs to kill infected cells. The mechanism underlying the regulation of PD-1 in activated and exhausted T cells is elusive. Recently, PD-1 upregulation via HIV Nef was shown to occur via a p38MAPK-dependent mechanism [30]. Several studies have confirmed that blockade of the STAT3, p38MAPK, NFATc, and PD-1 pathways results in enhanced T-cell proliferation in vitro [4,5,31]. Furthermore, the role of cytokine microenvironment, especially IL-2, IL-7, IL-15, and IL-21, in different tissues is emerging as one factor that can regulate PD-1/PD-L1 expression [32]. Importantly, transcriptional analyses of HIV-specific $\mathrm{CD}^{+}$ $\mathrm{T}$ cells have shown that PD-1 could inhibit T-cell functions by upregulating basic leucine zipper transcription factor ATF-like (BATF) [33]. Hence, the impact of PD-1 is found to span across many signaling cascades and transcriptional factors, and is worth investigating.

\section{b) CTLA-4}

CTLA-4 (CD152) belongs to the costimulatory family of molecules and represents the Ig superfamily signaling via B7-1/B7-2 on APCs (Figure 2). It is homologous to $\mathrm{CD} 28$, but unlike $\mathrm{CD} 28$ it is a negative regulator of immune responses [34,35]. Unlike CD28, whose expression is constitutive, CTLA-4 expression is induced on T cells 24-48 hours after activation and CTLA-4 has greater affinity for both B7-1 and B7-2 than CD28. Following T-cell activation, the sequential action of Lck, Fyn, and RLK phosphorylates CTLA-4 and transports it to the cell surface. This negative regulator is constitutively expressed on $\mathrm{CD} 4^{+} \mathrm{CD} 25^{+} \mathrm{FoxP}^{+}$Tregs, which suppress autoimmunity and maintain peripheral tolerance, whereas other T-cell subsets express this factor only following activation [34,36]. Early studies demonstrated that CTLA-4 was upregulated on total $\mathrm{CD}_{4}^{+} \mathrm{T}$ cells of individuals with progressive HIV disease and that there was a negative correlation between CTLA-4 expression and $\mathrm{CD}_{4}^{+}$T-cell count [37]. Furthermore, studies in HIV-infected individuals at different stages of infection revealed that CTLA-4 also is selectively upregulated on $\mathrm{HIV}$-specific $\mathrm{CD} 4^{+} \mathrm{T}$ cells in all categories of HIV-infected subjects besides long-term nonprogressors (LTNPs) [38,39]. In contrast to PD-1, CTLA-4 is highly expressed on HIV-specific $\mathrm{CD}^{+} \mathrm{T}$ cells $[25,40]$, but absent on HIV-specific $\mathrm{CD}^{+}$CTLs [38,39]. The HIV-specific $\mathrm{CD}^{+} \mathrm{T}$ cells with high CTLA-4 expression have impaired cytokine production and produce only IFN- $\gamma$, whereas cells with lower levels of CTLA-4 have the ability to secrete both IL-2 and IFN- $\gamma$ [39]. In vitro blockade of CTLA-4 enhances HIVspecific $\mathrm{CD}^{+}{ }^{+} \mathrm{T}$ cell functions, i.e. proliferation and IL-2 production [38], and decreases the susceptibility of these cells to become HIV infected [39].

\section{c) $T I M-3$}

TIM-3 belongs to the TIM family of molecules and TIM-1 through TIM-8 exist in mice, whereas humans express only TIM-1, TIM-3, and TIM-4 [41,42]. The TIM family members all have certain structural morphologies in common, i.e. an $\mathrm{N}$-terminal immunoglobulin $\mathrm{V}$ domain, a mucin domain, and a transmembrane domain followed by a cytoplasmic tail [41-43]. TIM-3 binds to Gal-9, an S-type lectin, and induces T-cell tolerance or to phosphatidylserine and induces cell death [44,45] (Figure 2). Blocking the interaction between TIM-3 and Gal-9 resulted in exacerbated autoimmunity and abrogation of tolerance in experimental models [46]. Recent studies have established that TIM-3 also promotes $\mathrm{CD}^{+}{ }^{+}$T-cell tolerance and myeloid-derived suppressor cell (MDSC) expansion in mice [47].

TIM-3 is expressed on Th1 cells and suppresses aggressive Th1 responses. TIM-3 expression is elevated on CD4 ${ }^{+}$ and $\mathrm{CD}^{+}{ }^{+} \mathrm{T}$ cells of HIV infected individuals [48-50]. We have shown that TIM-3 is expressed on T cells activated by HIV-pulsed DCs [2,4]. TIM-3 expressing $\mathrm{T}$ cells have poor proliferative abilities and dysfunctional cytokine responses, and in vitro blockade of TIM-3 results in improved proliferative ability for the HIV-specific T cells [50]. $\mathrm{CD}^{+} \mathrm{T}$ cell responses are crucial in controlling HIV1 infection, and their role is emphasized by the impact the type of HLA class I alleles can have on progression to AIDS [51,52]. Most HIV-specific $\mathrm{CD}^{+} \mathrm{T}$ cells upregulate TIM-3 when interacting with their antigen epitope on MHC I molecule complexes. Quite the opposite occurs when HLA-B*27- and HLA-B*57-restricted HIV-specific $\mathrm{CD}^{+} \mathrm{T}$ cells encounter their epitopes, which leads to less upregulation of TIM-3 expression but higher production of granzyme B [53]. This clearly indicates that HIVspecific $\mathrm{CD}^{+}$CTLs restricted by specific haplotypes can 
evade immune suppression and continue to proliferate and kill virus infected cells. TIM-3 and PD-1 are coexpressed on both $\mathrm{CD} 4^{+}$and $\mathrm{CD} 8^{+} \mathrm{T}$ cells derived from individuals with chronic HIV [54] or HCV [48,55,56] infections and are associated with more severe $\mathrm{CD} 8^{+}$ T-cell exhaustion [57]. Simultaneous blockade of PD-1 and TIM-3 pathways in vivo results in greater reversal of T-cell exhaustion and viral control compared to when only one of these pathways is blocked [57]. It has been shown that the STAT3/p38MAPK pathway contributes to upregulation of TIM-3 and therefore, it remains to be seen if blockade of TIM-3 upregulation contributes to improved functional abilities of Th1 cells in HIV infection.

\section{d) LAG-3}

LAG-3 (CD223) is a MHC II ligand belonging to the Ig superfamily expressed on activated and memory $\mathrm{T}$ cells, $B$ cells and NK cells, and is upregulated by IL-2, IL-7 and IL-12. It is structurally homologous to the CD4 receptor, and is implicated in mediating T-cell suppression [58,59]. The LAG-3 induced T-cell suppression reportedly occurs via CD3/TCR complex-associated LAG-3 molecules inhibiting CD3/TCR signaling and TCR-induced $\mathrm{Ca}^{2+}$-fluxes [60] (Figure 2). LAG-3 induction requires a weaker stimulation compared to PD-1 ligation [61].

Studies in mice models have found that LAG-3 is capable of inducing T-cell suppression and that LAG-3 expression was linked to functional exhaustion of $\mathrm{CD}^{+} \mathrm{T}$ cells in persistent infections [62-64]. $\mathrm{CD} 4^{+} \mathrm{CD} 25^{+} \mathrm{nTregs}$ express LAG-3 upon activation, and when this factor is deficient, i.e. in LAG- $3^{-/-}$mice, the cells exhibit impaired regulatory activity [60], which shows that LAG-3 contributes to the suppressor functions of Tregs. Furthermore, LAG-3 and PD-1 cooperate in the T-cell suppression and blockade of PD-1 and LAG-3 inhibitory receptor pathways improve $\mathrm{T}$-cell responses in a synergistic manner [61]. However, not all data regarding LAG-3 points to a suppressive effect. For instance, a recent study failed to show the suppressive effects of LAG-3 [65]. LAG-3 levels are elevated in subjects with HIV infection [59] and our recent in vitro results are consistent with the notion that HIV exposure could increase LAG-3 expression and that this factor could play a negative role in HIV infection [2-4]. However, the functional relevance of LAG-3 in regulating $\mathrm{T}$ cell responses in HIV infection remains to be investigated further to establish if the elevated levels of this factor are part of the immune suppression seen in HIV infection.

\section{e) $C D 160$}

CD160 is another member of the B7/CD28 family acting as a negative costimulatory receptor. It was originally identified as a MHC class I activating receptor on NK cells [64]. CD160 and BTLA binds both to the ligand HVEM expressed on APCs and activated T cells. Today, CD160 expression has been found on cytotoxic cells such as CD56 ${ }^{\mathrm{dim}} \mathrm{CD} 16^{-} \mathrm{NK}$ cells, NKT cells, $\gamma \delta \mathrm{T}$ cells, $\mathrm{CD} 8^{+}$ CD28 ${ }^{-} \mathrm{T}$ cells, intraepithelial $\mathrm{T}$ cells, and a small subset of peripheral $\mathrm{CD}^{+}$and $\mathrm{CD} 8^{+} \mathrm{T}$ cells [66], and this receptor negatively regulates cell cycle [67]. Normally, CD160 is expressed on $5 \%$ of the $\mathrm{CD}^{+} \mathrm{T}$ cells, but a population of $\mathrm{CD} 4^{+} \mathrm{CD} 160^{+}$cells can be fond in cutaneous inflammatory lesions [66,68]. CD160 expression is induced in a similar manner as CTLA-4 in T cells and mediates negative signaling [67]. When human $C D 4^{+} \mathrm{T}$ cells are activated, they upregulate CD160 expression and when this receptor is cross-linked with HVEM this strongly inhibits $\mathrm{CD} 4^{+}$ T-cell proliferation and cytokine production [69,70] (Figure 2). These findings clearly confirm CD160 as a negative regulator of $\mathrm{CD}^{+}{ }^{+} \mathrm{T}$-cell activation. The ex vivo expression level of CD160 is augmented in the lymphatic tissues derived from HIV-1-infected individuals during the acute stage of the disease [71]. In addition, CD160 expression is increased in acute and chronic HIV infections both on $\mathrm{CD}^{+} \mathrm{T}$ cells in general and on HIV-specific $\mathrm{CD} 8^{+} \mathrm{T}$ cells [28,71], which is in line with our recent observations in vitro $[2,4]$. Blockade of CD160 ligation with HVEM improves HIV-specific $\mathrm{CD}^{+}$T-cell proliferation and cytokine levels [29]. Recently, it has been reported that $\mathrm{CD} 160^{+} \mathrm{PD}-1^{+} \mathrm{CD} 8^{+} \mathrm{T}$ cells define a subset at an advanced stage of immune exhaustion [29] and this underlines the importance of co-expression of inhibitory molecules in HIV-associated T-cell exhaustion.

\section{f) BTLA}

BTLA (CD272) is a negative costimulatory molecule belonging to the B7/CD28 family. BTLA is constitutively expressed at low levels on naïve $B$ and $T$ cells, macrophages, DCs, NKT cells, and NK cells [66]. It binds to its cognate ligand HVEM, a member of the TNFR superfamily expressed on APCs and Tregs [66]. BTLA expression is upregulated following T-cell activation. Similarly to CD160, BTLA has impairing effects on the cell cycle (Figure 2) [69] and inhibits TCR-mediated signaling via ITIM and ITSM motifs [72]. Engagement of BTLA on T cells with its ligand HVEM inhibits effector $\mathrm{CD} 4^{+}$T-cell functions $[66,69,70]$. Although BTLA has been proposed to be a negative regulator of T-cell activation, its potential inhibitory function is still inconclusive in HIV-1 infection. Our studies showed that BTLA upregulation was indistinctive on HIV-infected T cells in vitro [2,4] while others have reported that HIV-1 infection could downregulate BTLA on $\mathrm{CD}_{4}^{+}$and $\mathrm{CD}^{+}$T cells [73,74]. A recent finding demonstrated that HIV-1 could induce BTLA downregulation on $\mathrm{CD} 4^{+} \mathrm{T}$ cells in vitro in an IFN- $\alpha$ dependent manner and this contributed to T-cell hyperactivation [73]. In agreement with this, dysregulation of B cells in HIV-1 infection has been associated with decreased BTLA 
expression on these cells in viremic individuals compared to aviremic individuals and healthy controls [1]. However, the functional significance of BTLA in HIV infection needs to be further evaluated.

\section{g) $2 B 4$}

2B4 (CD244) belongs to the signaling lymphocyte activation molecule (SLAM) family whose members are implicated in the regulation of costimulation, cytokines, and cytotoxic activities [75]. This transmembrane protein is expressed by all NK cells, monocytes, basophils, eosinophils, $\gamma \delta \mathrm{T}$ cells, and memory $\mathrm{CD}^{+} \mathrm{T}$ cells [75]. CD48 is the cognate ligand of $2 \mathrm{~B} 4$ and is expressed on NK cells [76]. 2B4 is an inhibitory receptor [77] regulating $\mathrm{CD}^{+} \mathrm{T}$-cell functions and its expression could be a marker of $\mathrm{CD}^{+}$T-cell impairment [76]. Cross-linking of $2 \mathrm{~B} 4$ with anti-2B4 mAb leads to NK-cell activation [76]. However, elevated 2B4 expression and relative paucity of signaling of 2B4's intracellular adaptor molecule SAP promote an inhibitory function of 2B4 (Figure 2) $[76,78]$. Studies have shown that 2B4 expression on NK cells is increased in HIV-1 infected patients [79]. Further, the proportion of $2 \mathrm{~B}^{+} \mathrm{CD}^{+} \mathrm{T}$ cells is associated with immune activation of memory $\mathrm{T}$ cells, which increases with disease progression [80]. It is also clear that the ability to produce IFN- $\gamma$ and cytotoxic activity of $\mathrm{HIV}$-specific $2 \mathrm{~B} 4^{+} \mathrm{CD} 8^{+} \mathrm{T}$ cells is relatively lower compared to influenza-specific $2 \mathrm{~B} 4^{+} \mathrm{CD} 8^{+} \mathrm{T}$ cells in HIV infected individuals [81], and in vitro blockade of 2B4 increases the proliferative capacity of HIV-specific $\mathrm{CD}^{+} \mathrm{T}$ cells [82]. Moreover, downregulation of SAP in $2 \mathrm{~B}^{+} \mathrm{CD}^{+} \mathrm{T}$ cells upon $\mathrm{HIV}$ stimulation suggests an inhibitory role of $2 \mathrm{~B} 4^{+} \mathrm{CD} 8^{+} \mathrm{T}$ cells against constrained HIV epitopes, underlining the inability to control HIV during disease progression.

\section{h) LILRB}

Members of the leucocyte immunoglobulin-like receptor B (LILRB) family are expressed on B cells, mast cells, macrophages, monocytes, osteoclasts, NK cells and DCs $[83,84]$ and are the human counterpart of the murine inhibitory molecule, PIR-B. Research has shown that LILRB1 can also be a T-cell factor that binds to HLA-A, HLA-B, HLA-F, HLA-G, and HCMV UL18 ligands $[83,84]$. DCs interaction with suppressor molecules on regulatory $\mathrm{T}$ cells rendered them tolerogenic by inducing upregulation of LILRB2 and LILRB4 [84]. High levels of LILRB1 and LILRB2 are observed during chronic HIV infection [85-87] and it has been shown that IL-10 upregulates LILRB2 in the monocytes of HIV-infected individuals, resulting in $\mathrm{CD}^{+}{ }^{+} \mathrm{T}$ cell depletion [88]. However, LILRB1 and LILRB3 expression on circulating myeloid DCs of HIV elite controllers contributes to greater antigen-presenting potentials and their blockade abrogates the antigen-presenting properties of DCs [89]. This indicates that the regulatory functions of various members of the LILRB family are multifaceted.

\section{i) TRAIL}

TRAIL is a member of the TNF superfamily, and functions as a proapoptotic ligand [90]. The two biologically active forms of TRAIL, membrane-bound (mTRAIL) and soluble TRAIL (sTRAIL), are regulated by type I IFNs $[91,92]$. sTRAIL is secreted by leukocytes, including T cells, NK cells, DCs, monocytes, and macrophages $[90,91,93]$. TRAIL can interact with DR4 and DR5 receptors, capable of inducing apoptosis [93,94] and three other receptors that facilitate suppression without initiating apoptosis [93] (Figure 2). The elevated mTRAIL levels on T cells exposed to HIV-pulsed DCs $[2,4]$ is intriguing because it can negatively regulate proliferation via mechanisms distinct from apoptosis [90]. Studies have shown that TRAIL is elevated in HIVinfected compared to uninfected subjects, and that when ART lowers the viral load dramatically, the TRAIL expression decreases [90]. Hence, TRAIL could be one potential inhibitory factor contributing to T-cell suppression in HIV infection.

\section{j) KLRG1}

KLRG1 is a member of the C-type lectin family of inhibitory receptors, which plays a unique but poorly characterized role in mediating $\mathrm{T}$-cell exhaustion $[95,96]$. Soluble E-cadherin is the ligand for KLRG1. KLRG1 is expressed on a subset of $\mathrm{CD}^{+}$and $\mathrm{CD}^{+} \mathrm{T}$ cells, as well as on NK cells, and inhibits $\mathrm{CD}^{+} \mathrm{T}$ cell cytotoxicity and cytokine production [95,96] (Figure 2). KLRG1 is upregulated on virus-specific $\mathrm{CD}^{+} \mathrm{T}$ cells in response to repetitive antigenic stimulation in PVIs such as CMV and EBV $[95,96]$. The presence of the KLRG1 ligand, soluble E-cadherin, impairs the KLRG1 ${ }^{\text {hi }}$ HIV-1-specific CD8 ${ }^{+}$T cells' ability to respond by cytokine secretion upon antigenic stimulation and to inhibit viral replication [77]. Furthermore, KLRG1 is coexpresssed with other inhibitory receptors, i.e. PD-1, CD160, and 2B4, on exhausted HCV-specific $\mathrm{CD}^{+} \mathrm{T}$ cells [77]. Of note, a recent study showed that knockout of KLRG1 in mice did not have an apparent effect on the phenotype, suggesting that KLRG1 might not contribute significantly to T cell exhaustion during HIV infection [97].

\section{Transcriptional factors and pathways}

Recent lines of evidence have highlighted the importance of inhibitory molecules and related pathways of T-cell exhaustion. However, the underlying transcriptional mechanisms remain for the most part elusive. In addition to the multiple inhibitory receptors that are involved in 
T-cell exhaustion, persistent changes in transcription patterns are observed when comparing the molecular signatures of exhausted $\mathrm{T}$ cells to functional $\mathrm{T}$ cells. These changes include altered expression of transcription factors, changes in signal transduction, and down-regulation of key metabolic genes [2].

\section{a) BLIMP-1}

BLIMP-1 (designated PRDI-BF1 in humans), a zinc fingercontaining evolutionarily conserved transcriptional repressor encoded by PRDM1, is an important factor implicated in the generation of terminally differentiated plasma cells [98]. BLIMP-1 has also been reported to be a master regulator of terminal differentiation of $\mathrm{CD}^{+}$T-cells [99]. Recently, it has been shown that its elevated expression directly correlates with the upregulation of an array of cell surface inhibitory molecules in chronic viral infection [63] (Figure 1). BLIMP-1 attenuates T-cell proliferation and $\mathrm{CD}^{+}{ }^{+}$Treg functions, and its expression is reportedly enhanced in antigen-experienced T cells [100-102]. BLIMP-1 promotes the overexpression of inhibitory receptors and also suppresses key molecules involved in normal memory $\mathrm{CD}^{+}$T-cell differentiation, such as IL-7 receptor and CD62L [63]. Moreover, coexpression of FoxP3 and BLIMP-1 could be vital for suppressor functions as FoxP3 reportedly leads to activation of BLIMP-1 in antigenexposed T-cells [102]. Intriguingly, high BLIMP-1 expression correlates with increased PD-1, CTLA-4, and CD160 expression in chronic HIV infection [63]. During acute infection, smaller amounts of BLIMP-1 are associated with terminal differentiation of effector FoxP3 ${ }^{+} \mathrm{CD}^{+} \mathrm{T}$ cells [102], whereas high BLIMP-1 expression during chronic infection promotes upregulation of inhibitory receptors including PD-1, LAG-3, CD160 and 2B4, resulting in exhausted $\mathrm{CD}^{+} \mathrm{T}$ cells [63]. While lack of BLIMP-1 gives defective cytolytic function in virus-specific $\mathrm{CD}^{+} \mathrm{T}$ cells and low expression of KLRG1 [77], the potential role of BLIMP-1 in the upregulation of multiple inhibitory molecules is clear in chronic viral infections, especially in LCMV and HIV-1 infection [2,4,63,103]. We have demonstrated that BLIMP-1 is induced in CD4 ${ }^{+} \mathrm{T}$ cells stimulated by HIV-exposed DCs [2,4] and recent lines of evidence points to the existence of a novel miR-9/BLIMP$1 / \mathrm{IL}-2$ axis that is compromised in progressive HIV disease but not in LTNPs [104,105]. BLIMP-1 is upregulated in $\mathrm{CD}^{+}{ }^{+} \mathrm{T}$ cells via TCR stimulation and IL-2 and this is regulated by miR-9 levels. The upregulation of miR-9 induces BLIMP-1 repression, leading to restoration of IL-2 secretion by $\mathrm{CD} 4^{+} \mathrm{T}$ cells, which occurs by reduced binding potential of BLIMP-1 to the il-2 promoter $[104,105]$.

\section{b) FoxP3}

FoxP3 regulates $\mathrm{CD}^{+}{ }^{+} \mathrm{T}$-cell activation and FoxP3 expression is elevated in $\mathrm{T}$ cells upon stimulation leading to suppressive functions (Figure 1) [106] and HIV and SIV infections can give rise to FoxP3 expression in $\mathrm{T}$ cells [106-111]. Recent findings associated increased Fox P3 expression with the onset of $\mathrm{T}$ cell dysfunction in HIV/AIDS [112]. Interestingly, high CTLA-4 expression on Tregs depends on FoxP3 along with NFAT [111,113]. The elevated expression of FoxP3 and BLIMP-1 in T cells primed with HIV-pulsed DCs suggests a potential direct role of FoxP3 in controlling BLIMP-1 expression in antigen-exposed $\mathrm{T}$ cells [2,4]. This is consistent with prior observations from a genome-wide investigation, which showed that BLIMP-1 is directly activated by FoxP3, adding a key dimension to the notion that BLIMP-1 is necessary for accurate function of suppressor T cells [101].

\section{c) T-bet}

T-bet, encoded by $T b x 21$ gene, is the key regulator of the Th1 phenotype differentiation system. It induces the synthesis of IFN- $\gamma$ and regulates the expression of chemokines and chemokine to orchestrate Th1 cell differentiation. Expression of T-bet together with granzyme $\mathrm{A}$ and $\mathrm{B}$, granulysin, and perforin has been assessed in HIV-specific $\mathrm{CD}^{+} \mathrm{T}$ cells derived from elite controllers, progressors, and ART treated individuals [114]. Interestingly, the HIV-specific $\mathrm{CD}^{+} \mathrm{T}$ cells from elite controllers had greater capacity for granzyme B and perforin expression relative to the other groups [114] and level of T-bet expression in HIV-specific $\mathrm{CD}^{+} \mathrm{T}$ cells correlated with granzyme $\mathrm{B}$ and perforin levels [114]. Hence, it has been suggested that T-bet can regulate the expression of perforin and granzyme $\mathrm{B}$ by binding to the promoter regions of these genes [115-117]. In chronic LCMV, T-bet directly represses the gene promotor for PD-1 in a site-specific manner, which leads to lower expression of PD-1 and other inhibitory receptors $[117,118]$. It was also demonstrated that genetic ablation of T-bet leads to exacerbation of $\mathrm{CD}^{+} \mathrm{T}$-cell exhaustion and increase of viral load [118]. BLIMP-1 and T-bet seem to have similar roles in promoting the effector function and terminal differentiation of $\mathrm{CD}^{+} \mathrm{T}$ cells during acute infection [102,117]. High T-bet expression promotes terminally differentiated CD $127^{\mathrm{lo}}$ KLRG- $1^{\text {hi }}$ effector $\mathrm{CD}^{+} \mathrm{T}$ cells and sustains functional virus-specific $\mathrm{CD}^{+} \mathrm{T}$-cell responses [117]. Exhausted $\mathrm{CD} 8^{+} \mathrm{T}$ cells have downmodulated T-bet levels due to persistent antigenic stimulation results in exhausted $\mathrm{CD}^{+} \mathrm{T}$ cells [117]. Whereas the exact mechanism of repression of T-bet expression is unknown, deficiency of T-bet leads to attenuated BLIMP-1 expression in NK cells [119], and the same effect may be expected in the $\mathrm{CD}^{+}$cell, as BLIMP-1 and T-bet-deficient $\mathrm{CD}^{+} \mathrm{T}$ cells show similar differentiation phenotypes [102,120,121]. 


\section{d) BATF}

BATF has been identified as a negative regulator of AP-1 by forming dimers with c-Jun [122], which inhibit canonical AP-1-mediated transcription, and this contributes to $\mathrm{T}$ cell exhaustion [123]. BATF regulates effector $\mathrm{CD}^{+}$ T-cell differentiation via Sirt1 expression [124,125]. PD-1 ligation can inhibit $\mathrm{T}$ cell functions by enhancing BATF expression and this has been documented in HIV-specific $\mathrm{CD}^{+} \mathrm{T}$ cells derived from infected individuals [33]. It has also been shown that BATF overexpression in activated primary human $\mathrm{T}$ cells impairs $\mathrm{T}$-cell proliferation and IL-2 production, whereas silencing BATF expression in HIV-specific T cells increases their proliferation, as well as IFN- $\gamma$ and IL-2 production [33,124], confirming that BATF plays a role in T cell dysfunction during HIV infection. In addition, BATF is also required for the differentiation of IL17-producing Th17 cells, which coordinate inflammatory responses in host defense [125].

\section{e) P38MAPK/STAT3}

The STAT3 pathway can be activated either by IL-10 and IL-6 cytokines or by growth factors such as VEGF, TGF- $\beta$, G-CSF, PDGF, EGF and MAPkinases [126,127]. Recently, we have reported that p38MAPK/STAT3 pathways were involved in HIV-1 mediated upregulation of inhibitory receptors CTLA-4, TRAIL, TIM-3, LAG-3, CD160 and transcription factors BLIMP-1, DTX1, and FoxP3, as their blockade abolished expression of inhibitory molecules and restored T-cell proliferation in vitro [4]. Specifically, it has been found that HIV Nef mediates PD-1 upregulation via a p38MAPK-dependent mechanism [30].

\section{g) NFATc1 and DTX1}

An impaired NFAT nuclear translocation is observed in exhausted $\mathrm{CD}^{+} \mathrm{T}$ cells during chronic HIV and LCMV infections [128,129]. The nuclear translocation of NFATc1 (NFAT2) was more efficient in HIV-specific $\mathrm{CD}^{+} \mathrm{T}$ cells derived from LTNPs relative to individuals with disease progression [130]. Inhibition of calcineurin or NFAT leads to sharp reduction in PD-1 expression suggesting a regulatory role for calcineurin/NFAT signaling pathway $[129,130]$. However, it remains to be investigated how altered nuclear translocation of NFATc1 and PD-1 expression are associated with exhausted T cells. DTX1 is a transcription target of NFAT, and upregulation of DTX1 inhibits T-cell activation by both E3-dependent and E3-independent mechanisms [131]. Recently, we reported that HIV-1 induced increased expression of DTX1 mRNA in the T cells primed by HIV-1 exposed DCs, which correlated with increased NFAT mRNA [4]. We also found that inhibition of NFAT decreased DTX1 and PD-1 mRNA and protein expression.

\section{h) Miscellaneous pathways}

FOxO3a FOxO3a is a transcription factor constitutively expressed in hematopoietic cells that can promote the transcription of certain proapoptotic target genes e.g. Bim, FasL, and TRAIL [132]. HIV TAT-induced FOXO3a in association with these factors reportedly play a major role in mediating the apoptosis of HIV-1-infected human $\mathrm{CD}^{+} \mathrm{T}$ cells [133]. A study showed that FOxO3a/TRAIL signaling has a direct role in the persistence of memory $\mathrm{B}$ cells during HIV infection [134]. Transcriptional activity of FOxO3a and expression of TRAIL have been found to be higher in aviremic treated individuals compared to elite controllers and uninfected individuals and have been attributed to low survival rates of memory B cells [134].

Socs 3 Socs 3 has recently been shown to facilitate T-cell exhaustion in chronic infections [135]. LCMV-specific T cells in chronic infection express higher levels of Socs3, whereas Socs3 deficiency leads to enhanced T cell functions. Interestingly, IL-7 treatment results in decreased levels of Socs 3 and reinvigorates the immune response to chronic virus infection $[135,136]$. Hence, downregulation of Socs3 using IL-7 is likely to contribute to improve T-cell functions. The role of Socs3 in HIV-1 infection remains to be investigated.

Hippo pathway The Hippo pathway is a highly conserved developmental system, which directly controls terminal differentiation of multiple cell types in invertebrates and vertebrates [137]. Recently, it was shown that activation of the Hippo pathway by CTLA-4 regulates the expression of BLIMP-1 in CD8 ${ }^{+}$T cells [121]. The CTLA-4/Hippo pathway/BLIMP-1 system may link terminal differentiation of $\mathrm{CD}^{+} \mathrm{T}$ cells [121]. However, the precise role of the association of CTLA-4/Hippo/BLIMP-1 network in HIV infection remains to be elucidated.

\section{Immunoregulatory cytokines and enzymes a) IDO}

IDO is an intracellular enzyme that catalyses the catabolism of tryptophan. IFN- $\gamma$ is the primary inducer of IDO while other factors such as TNF- $\alpha$, TNF- $\beta$ and lipopolysaccharide can induce IDO to a limited extent $[138,139]$. In 2002, it became evident that CTLA-4 ligation to B7 resulted in the induction of an $\mathrm{IDO}^{+}$immunosuppressive DC phenotype (Figure 1) [40]. Subsequently, CTLA-4/B7mediated IDO induction was observed in myeloid DCs, pDCs, and MDDCs [140,141]. Increased IDO activity leads to apoptosis of effector $\mathrm{T}$ cells and induction of Tregs thereby dampening an active immune response [142]. These Tregs participate in a positive feedback loop via CTLA-4 engagement of B7 molecules, which stimulate increased IFN- $\gamma$ production from APCs and subsequent enhancement of IDO activity [142]. The reduction of 
plasma concentration of tryptophan in HIV-1 patients was first reported in 1988 [143] and thereafter it has been shown that HIV infection could result in increased IDO activity [144]. It is becoming clear that TGF- $\beta 1$ signaling through a PI3K-dependent or a SMAD-independent pathway can induce Fyn-dependent phosphorylation of IDO ITIMs [145], which leads to activation of noncanonical NF$\mathrm{kB}$ to activate IDO signaling [145]. Therefore, approaches blocking the IDO pathway may be a potential strategy to improve T-cell functions in HIV-infected patients.

\section{b) IL-10}

IL-10 was first recognized for its ability to inhibit activation of T cells, B cells, monocytes, and macrophages, and also to terminate inflammatory responses [146,147]. IL-10 is produced by $\mathrm{CD}^{+} \mathrm{T}$ cells, including Tregs, $\mathrm{CD}^{+} \mathrm{T}$ cells, DCs, macrophages, and B cells [146,147]. Increase in IL-10 levels has been reported in PVIs, including HIV and HCV [148]. Interestingly, it has been shown that IL-10 and PD-L1 pathways work in synergy to suppress T-cell activation during persistent LCMV infection, and that blockade of both IL-10 and PD-L1 more effectively restores antiviral $\mathrm{T}$-cell responses than blockade of either one alone [149]. The PD-1-induced IL-10 production by monocytes could impair $\mathrm{CD}^{+} \mathrm{T}$ cell activation during HIV infection [150]. Furthermore, the levels of serum IL10 and IL-10 mRNA in PBMCs are reported to increase with HIV disease progression [151] and IL-10 reversibly inhibits virus-specific $\mathrm{T}$ cells [152]. Blockade of IL-10 restored Env- specific T-cell proliferative responses to a high degree [153], although, this ability was eventually lost during advanced HIV disease [152].

\section{c) TGF- $\beta$}

TGF- $\beta$ is an immunoregulatory cytokine that is implicated in controlling immune responses and maintaining immune homeostasis by affecting proliferation, differentiation, and survival of multiple immune cell lineages [154]. Upregulation of TGF- $\beta$ and IL-10 is associated with disease progression in HIV-1-infected individuals [155]. TGF- $\beta$ upregulates CTLA-4 expression and suppresses IL-2 production and T cell proliferation [156]. Moreover, it has been reported that TGF- $\beta$ and IL-10 production by HIV-specific $\mathrm{CD}^{+} \mathrm{T}$ cells regulates CTLA- 4 signaling on $\mathrm{CD}^{+} \mathrm{T}$ cells [155]. Noteworthy is that blockade of TGF- $\beta$ did not improve control of chronic LCMV infection [157,158], which suggests that blocking this factor alone might not have any effect on the control of HIV-1 infection.

\section{Conclusion}

Our improved understanding of the T-cell costimulation and coinhibition pathways attained over the past decade has given plenty of evidence on the key roles played by these molecules in immune homeostasis. However, numerous infectious agents and tumors escape from host immune surveillance by efficiently upregulating coinhibitory signals. It is now clear that coexpression of multiple distinct inhibitory receptors is associated with greater T cell exhaustion and rapid HIV disease progression. It has also been established by researchers that T-cell inhibition results from progressive sequential accumulation of a broad array of inhibitory molecules in HIV infection. Hence, measures to understand their contribution to T-cell suppression and target the molecular and biochemical signaling networks that converge to inhibit $\mathrm{T}$-cell activation need to be further investigated. Our recent findings have shown that inhibitory molecules are under the control of diverse pathways, i.e. PD-1 is upregulated by both p38MAPK/ STAT3 and NFAT pathways, whereas CTLA-4, TRAIL, LAG-3, CD160 and TIM-3 are regulated by p38MAPK/ STAT3. Of interest to further elucidate is for instance how HIV-1 exploits DCs, inducing them to secrete retinoic acid, which is believed to trigger the differentiation of tolerogenic T cells. Further, it is clear that inhibitory receptors are potential targets of therapeutics in HIV infection and therefore it is important to decode the molecular signatures of T-cell suppression as this might open up for new drugs targeting inhibitory molecules, transcriptional repressors and pathways in HIV infected individuals.

Although there is no experimental evidence, one approach we suggest is to block inhibitory molecules, especially PD-1/PD-L1, to amplify antiviral T-cell functions to a level sufficient enough to purge latent viral reservoirs. Certain key questions still remain to be answered; will the therapeutic use of targeting inhibitory molecules in HIV be toxic to HIV-infected individuals? What will be the magnitude of damage caused to the house-keeping functions of the coinhibitory molecules targeted? Will this targeting bring any additional benefit to ART-treated subjects? Exploring these areas may be necessary to ensure successful response of chronic HIV infected patients to anti-inhibitory molecular therapeutics. Therefore, the prime objective would be to facilitate complete functional restoration of T-cell functions, which may rely on combination therapies targeting diverse sets of host cellular factors at different stages of HIV infection. Given the emergence of a wider network of inhibitory molecules in HIV infection, additional studies may be required to investigate the molecular targets associated with restoration of T-cell functions to increase longevity and quality of life of HIV-infected individuals.

\section{Definitions}

Exhausted $\mathbf{T}$ cells Memory $\mathrm{T}$ cells that assume a state of unresponsiveness following activation by certain viral antigens that are noticeable during subsequent antigenic stimulation [159]. 


\section{Regulatory $T$ cells (Tregs)}

1. Natural Tregs (nTregs) $\mathrm{CD} 4{ }^{+} \mathrm{CD} 25^{+} \mathrm{CD} 127^{\text {low }}$ phenotype cells that develop in the thymus. nTregs are CTLA $-4^{+}$GITR $^{+}$Foxp $3^{+}$. They facilitate auto reactive T-cell suppression by contact, cytolytic mechanisms, or by TGF- $\beta$. nTregs expand in vivo following TCR/ CD28 stimulation and by expressing receptors for IL-2. 2. Induced Tregs (iTreg) Non-regulatory CD4 ${ }^{+} \mathrm{T}$ cells, which acquire CD25 (IL-2R $\alpha$ ) expression outside of the thymus. a) Tr1: CD4 ${ }^{+}$CD25- phenotype that develops in the periphery. Tr1 cells are marked by CD45RB ${ }^{\text {low }}$ Foxp3and mediate suppression via IL-10. Tr1 cells expand following CD3 signaling leading to secretion of IL-10 and retinoic acid. b) Tr3: $\mathrm{CD}^{+}{ }^{+} \mathrm{CD} 25^{+}$, develop in the periphery under the influence of TGF- $\beta$ from $C D 4^{+}$ CD25-Treg precursors. Tr3 cells are marked by CD25 ${ }^{\text {low-variable }} \mathrm{CD}_{45 \mathrm{RB}^{\text {low }}} \mathrm{Foxp}^{+}$and mediate suppression via TGF- $\beta$. Expand following CD3 signaling leading to secretion of TGF- $\beta$.

Suppressor $\mathbf{T}$ cells $\mathrm{T}$ cells that arise following priming by HIV-exposed DCs. Suppressor T cells reportedly express numerous molecules that could facilitate T-cell inhibition in a contact-dependent manner [2-4].

\section{Abbreviations}

AIDS: Acquired immunodeficiency syndrome; APC: Antigen-presenting cell; ART: Antiretroviral treatment; BATF: Basic leucine zipper transcription factor ATF-like; BCl-xL: B-cell lymphoma-extra large; BLIMP-1: B-lymphocyte-induced maturation protein; BTLA: $B$ and T-lymphocyte attenuator;

CMV: Cytomegalovirus; CTLA-4: Cytotoxic T-lymphocyte antigen-4; CTL: Cytotoxic T lymphocyte; DC: Dendritic cell; DTX1: Deltex homolog 1 protein; EAT2: Ewing's sarcoma-Fli1-activated transcript 2; EBV: Epstein-barr virus; EGF: Epidermal growth factor; FoxP3: Fork-head transcription factor P3; Gal-9: Galectin-9; G-CSF: Granulocyte colony stimulating factor;

GITR: Glucocorticoid-induced tumor necrosis factor receptor; HBV: Hepatitis B virus; HCV: Hepatitis C virus; HIV-1: Human immunodeficiency virus type-1; HLA: Human leukocyte antigen; HSV: Herpes simplex virus; ICOS: Inducible T-cell costimulator; IDO: Indoleamine 2, 3-dioxygenase; IFN-ץ: Interferongamma; IL-6: Interleukin-6; IL-7: Interleukin-7; IL-10: Interleukin-10; ITIM: Immunoreceptor tyrosine-based inhibitory motif; iTregs: Inducible regulatory T cells; ITSM: IT-based switch motif; JAK: Janus Kinase; KLRG1: Killer cell lectin-like receptor G1; LAG-3: Lymphocyte activation gene3; LCK: Lymphocyte cell kinase; LCMV: Lymphocytic choriomeningitis virus; LILR: Leukocyte Ig-like receptor; LILRB: LIL receptor B; LILRB1: LILRB member 1; LPS: Lipopolysaccharide; LTNP: Long-term non-progressor; 1-MT: 1-methyltryptophan; mAb: Monoclonal antibody; mDC: myeloid dendritic cell; MDDC: Monocyte-derived dendritic cell; miR-9: MicroRNA-9; mTRAIL: Membrane-bound tumor-necrosis factor-related apoptosis-inducing ligand; MDSC: Myeloid-derived suppressor cell; NAD+: Nicotinamide adenine dinucleotide; NFATc: Nuclear factor associated with transcription; NK: Natural killer cell; NKT: NK T cell; nTregs: Natural regulatory T cells; mRNA: Messenger RNA; P38MAPK: p38 mitogen-activated protein kinase; PBMC: Peripheral blood mononuclear cell; PD-1: Programmed death-1; pDC: Plasmacytoid DC; PDGF: Platelet-derived growth factor; PI3K: Phosphatidylinositol 3-kinase; PIRB: Paired Ig-like receptor B; PKCO: Protein kinase C theta; PVI: Persistent viral infection; PRDM1: Positive regulatory domain 1-binding factor; RLK: Resting lymphocyte kinase; SAP: SLAM-associated protein; siRNA: Small interfering RNA; SIV: Simian immunodeficiency virus; Socs3: Suppressor of cytokine signaling 3; STAT3: Signal transducer and activator of transcription 3; TCR: T-cell receptor; TGF- $\beta 1$ : Transforming growth factor-beta1; TIM-3: T-cell immunoglobulin mucin-containing domain-3; TNF: Tumor necrosis factor;
TRAIL: TNF-related apoptosis-inducing ligand; Treg: Regulatory T cell; VEGF: Vascular endothelial growth factor; ZAP-70: Zeta-chain-associated protein kinase-70.

\section{Competing interests}

The authors declare that they have no competing interests.

\section{Authors' contributions}

$M L, E M S, K F C, R E, A S$ and $W$ generated the initial manuscript draft and the figures; VR, RA, RE, $A K, M B, R R$ and $M L$ contributed to writing and jointly developed the article to its final form. All authors read and approved the final manuscript.

\section{Acknowledgements}

The authors acknowledge funding support provided for this work by the University of Malaya Research Grant (UMRG) of the Health and Translational Medicine Research Cluster, University of Malaya, Kuala Lumpur, to EMS (RG448-12HTM). ML is supported through Al52731, the Swedish Research Council, the Swedish Physicians against AIDS Research Foundation, the Swedish International Development Cooperation Agency; SIDA SARC, VINNMER for Vinnova, Linköping University Hospital Research Fund, CALF and the Swedish Society of Medicine. AK receives funding support from the Ministry of Higher Education Malaysia, High Impact Research Grant (HIRGA E000001-20001).

\section{Author details}

${ }^{1}$ Molecular Virology, Department of Clinical and Experimental Medicine, Linköping University, 58185 Linköping, Sweden. ${ }^{2}$ Tropical Infectious Disease Research and Education Center (TIDREC), Department of Medical Microbiology, Faculty of Medicine, University of Malaya, 50603 Lembah Pantai, Kuala Lumpur, Malaysia. ${ }^{3}$ Institute for Environmental Medicine, Karolinska Institute, Solna 17 177Stockholm, Sweden. ${ }^{4}$ Centre of Excellence for Research in AIDS (CERiA), Department of Medicine, Faculty of Medicine, University of Malaya, 50603 Lembah Pantai, Kuala Lumpur, Malaysia. ${ }^{5}$ Department of Microbiology and Immunology, Emory Vaccine Center, Emory University, 954 Gatewood Road, Atlanta, GA 30329 USA.

Received: 13 January 2013 Accepted: 7 March 2013

Published: 20 March 2013

\section{References}

1. Boliar S, Murphy MK, Tran TC, Carnathan DG, Armstrong WS, Silvestri G, Derdeyn CA: B-lymphocyte dysfunction in chronic HIV-1 infection does not prevent cross-clade neutralization breadth. J Virol 2012, 86:8031-8040.

2. Shankar EM, Che KF, Messmer D, Lifson JD, Larsson M: Expression of a broad array of negative costimulatory molecules and Blimp-1 in T cells following priming by HIV-1 pulsed dendritic cells. Mol Med 2011, 17:229-240.

3. Che KF, Sabado RL, Shankar EM, Tjomsland V, Messmer D, Bhardwaj N, Lifson JD, Larsson M: HIV-1 impairs in vitro priming of naive T cells and gives rise to contact-dependent suppressor T cells. Eur J Immunol 2010, 40:2248-2258.

4. Che KF, Shankar EM, Muthu S, Zandi S, Sigvardsson M, Hinkula J, Messmer D, Larsson M: p38 mitogen-activated protein kinase/signal transducer and activator of transcription-3 pathway signaling regulates expression of inhibitory molecules in T cells activated by HIV-1-exposed dendritic cells. Mol Med 2012, 18:1169-1182.

5. Weiss L, Donkova-Petrini V, Caccavelli L, Balbo M, Carbonneil C, Levy $Y$ Human immunodeficiency virus-driven expansion of CD4 + CD25+ regulatory T cells, which suppress HIV-specific CD4 T-cell responses in HIV-infected patients. Blood 2004, 104:3249-3256.

6. Mojumdar K, Vajpayee M, Chauhan NK, Singh A, Singh R, Kurapati S: Loss of CD127 and increased immunosenescence of T cell subsets in HIV infected individuals. Indian J Med Res 2011, 134:972-981.

7. Murooka TT, Deruaz M, Marangoni F, Vrbanac VD, Seung E, von Andrian UH, Tager AM, Luster AD, Mempel TR: HIV-infected T cells are migratory vehicles for viral dissemination. Nature 2012, 490:283-287.

8. Migueles SA, Weeks KA, Nou E, Berkley AM, Rood JE, Osborne CM, Hallahan CW, Cogliano-Shutta NA, Metcalf JA, McLaughlin M, et al: Defective human immunodeficiency virus-specific CD8+ T-cell polyfunctionality, 
proliferation, and cytotoxicity are not restored by antiretroviral therapy. J Virol 2009, 83:11876-11889.

9. Shankar EM, Solomon SS, Vignesh R, Murugavel KG, Sundaram M, Solomon S, Balakrishnan P, Kumarasamy N: GB virus infection: a silent anti-HIV panacea within? Trans R Soc Trop Med Hyg 2008, 102:1176-1180.

10. Riley JL, Schlienger K, Blair PJ, Carreno B, Craighead N, Kim D, Carroll RG, June CH: Modulation of susceptibility to HIV-1 infection by the cytotoxic T lymphocyte antigen 4 costimulatory molecule. J Exp Med 2000, 191:1987-1997.

11. Wilkinson J, Cunningham AL: Mucosal transmission of HIV-1: first stop dendritic cells. Curr Drug Targets 2006, 7:1563-1569.

12. von Andrian UH, Mempel TR: Homing and cellular traffic in lymph nodes. Nat Rev Immunol 2003, 3:867-878.

13. Leitner J, Grabmeier-Pfistershammer K, Steinberger P: Receptors and ligands implicated in human T cell costimulatory processes. Immunol Lett 2010, 128:89-97.

14. Bertram EM, Dawicki W, Sedgmen B, Bramson JL, Lynch DH, Watts TH: A switch in costimulation from $\mathrm{CD} 28$ to $4-1 \mathrm{BB}$ during primary versus secondary CD8 T cell response to influenza in vivo. J Immunol 2004, 172:981-988.

15. Coyle AJ, Gutierrez-Ramos JC: The expanding B7 superfamily: increasing complexity in costimulatory signals regulating $\mathrm{T}$ cell function. Nat Immunol 2001, 2:203-209.

16. Chen L: Co-inhibitory molecules of the B7-CD28 family in the control of T-cell immunity. Nat Rev Immunol 2004, 4:336-347.

17. Greenwald RJ, Freeman GJ, Sharpe AH: The B7 family revisited. Annu Rev Immunol 2005, 23:515-548.

18. Parry RV, Chemnitz JM, Frauwirth KA, Lanfranco AR, Braunstein I, Kobayashi SV, Linsley PS, Thompson CB, Riley JL: CTLA-4 and PD-1 receptors inhibit T-cell activation by distinct mechanisms. Mol Cell Biol 2005, 25:9543-9553

19. Freeman GJ, Wherry EJ, Ahmed R, Sharpe AH: Reinvigorating exhausted HIV-specific T cells via PD-1-PD-1 ligand blockade. J Exp Med 2006, 203:2223-2227.

20. Okazaki T, Honjo T: The PD-1-PD-L pathway in immunological tolerance. Trends Immunol 2006, 27:195-201.

21. Brown JA, Dorfman DM, Ma FR, Sullivan EL, Munoz O, Wood CR, Greenfield EA, Freeman GJ: Blockade of programmed death-1 ligands on dendritic cells enhances T cell activation and cytokine production. J Immunol 2003, 170:1257-1266.

22. Barber DL, Wherry EJ, Masopust D, Zhu B, Allison JP, Sharpe AH, Freeman GJ, Ahmed R: Restoring function in exhausted CD8 T cells during chronic viral infection. Nature 2006, 439:682-687.

23. Day CL, Kaufmann DE, Kiepiela P, Brown JA, Moodley ES, Reddy S, Mackey EW, Miller JD, Leslie AJ, DePierres C, et al: PD-1 expression on HIV-specific $\mathrm{T}$ cells is associated with T-cell exhaustion and disease progression. Nature 2006, 443:350-354.

24. Trautmann L, Janbazian L, Chomont N, Said EA, Gimmig S, Bessette B, Boulassel MR, Delwart E, Sepulveda H, Balderas RS, et al: Upregulation of PD-1 expression on HIV-specific CD8+ T cells leads to reversible immune dysfunction. Nat Med 2006, 12:1198-1202.

25. Wang X, Zhang Z, Zhang S, Fu J, Yao J, Jiao Y, Wu H, Wang FS: B7-H1 upregulation impairs myeloid $D C$ and correlates with disease progression in chronic HIV-1 infection. Eur J Immunol 2008, 38:3226-3236.

26. Frebel H, Nindl V, Schuepbach RA, Braunschweiler T, Richter K, Vogel J, Wagner CA, Loffing-Cueni D, Kurrer M, Ludewig B, Oxenius A: Programmed death 1 protects from fatal circulatory failure during systemic virus infection of mice. J Exp Med 2012, 17:2485-2499.

27. Velu V, Titanji K, Zhu B, Husain S, Pladevega A, Lai L, Vanderford TH, Chennareddi L, Silvestri G, Freeman GJ, et al: Enhancing SIV-specific immunity in vivo by PD-1 blockade. Nature 2009, 458:206-210

28. Petrovas C, Casazza JP, Brenchley JM, Price DA, Gostick E, Adams WC, Precopio ML, Schacker T, Roederer M, Douek DC, Koup RA: PD-1 is a regulator of virus-specific CD8+ T cell survival in HIV infection. J Exp Med 2006, 203:2281-2292.

29. Peretz Y, He Z, Shi Y, Yassine-Diab B, Goulet JP, Bordi R, Filali-Mouhim A, Loubert JB, El-Far M, Dupuy FP, et al: CD160 and PD-1 co-expression on HIV-specific CD8 T cells defines a subset with advanced dysfunction. PLoS Pathog 2012, 8:e1002840.

30. Muthumani K, Choo AY, Shedlock DJ, Laddy DJ, Sundaram SG, Hirao L, Wu L, Thieu KP, Chung CW, Lankaraman KM, et al: Human immunodeficiency virus type 1 Nef induces programmed death 1 expression through a p38 mitogen-activated protein kinase-dependent mechanism. J Virol 2008, 82:11536-11544.

31. Oestreich $\mathrm{K}$, Yoon H, Ahmed R, Boss JM: NFATc1 regulates PD-1 expression upon T cell activation. J Immunol 2008, 181:4832-4839.

32. Kinter AL, Godbout EJ, McNally JP, Sereti I, Roby GA, O'Shea MA, Fauci AS: The common gamma-chain cytokines IL-2, IL-7, IL-15, and IL-21 induce the expression of programmed death-1 and its ligands. J Immunol 2008 , 181:6738-6746.

33. Quigley M, Pereyra F, Nilsson B, Porichis F, Fonseca C, Eichbaum Q, Julg B, Jesneck JL, Brosnahan K, Imam S, et al: Transcriptional analysis of HIVspecific CD8+ T cells shows that PD-1 inhibits T cell function by upregulating BATF. Nat Med 2010, 16:1147-1151.

34. Salomon B, Lenschow DJ, Rhee L, Ashourian N, Singh B, Sharpe A, Bluestone JA: B7/CD28 costimulation is essential for the homeostasis of the $\mathrm{CD} 4+\mathrm{CD} 25+$ immunoregulatory $\mathrm{T}$ cells that control autoimmune diabetes. Immunity 2000, 12:431-440.

35. Read S, Malmstrom V, Powrie F: Cytotoxic T lymphocyte-associated antigen 4 plays an essential role in the function of CD25(+)CD4(+) regulatory cells that control intestinal inflammation. J Exp Med 2000 192:295-302.

36. Wing K, Onishi Y, Prieto-Martin P, Yamaguchi T, Miyara M, Fehervari Z, Nomura T, Sakaguchi S: CTLA-4 control over FoxP3+ regulatory T cell function. Science 2008, 322:271-275.

37. Leng Q, Bentwich Z, Magen E, Kalinkovich A, Borkow G: CTLA-4 upregulation during HIV infection: association with anergy and possible target for therapeutic intervention. AIDS 2002, 16:519-529.

38. Kaufmann DE, Kavanagh DG, Pereyra F, Zaunders JJ, Mackey EW, Miura T, Palmer S, Brockman M, Rathod A, Piechocka-Trocha A, et al: Upregulation of CTLA-4 by HIV-specific CD4+ T cells correlates with disease progression and defines a reversible immune dysfunction. Nat Immunol 2007, 8:1246-1254

39. Kaufmann DE, Walker BD: PD-1 and CTLA-4 inhibitory cosignaling pathways in HIV infection and the potential for therapeutic intervention. J Immunol 2009, 182:5891-5897.

40. Grohmann U, Orabona C, Fallarino F, Vacca C, Calcinaro F, Falorni A, Candeloro P, Belladonna ML, Bianchi R, Fioretti MC, Puccetti P: CTLA-4-Ig regulates tryptophan catabolism in vivo. Nat Immunol 2002, 3:1097-1101.

41. Kuchroo VK, Dardalhon V, Xiao S, Anderson AC: New roles for TIM family members in immune regulation. Nat Rev Immunol 2008, 8:577-580.

42. Kuchroo VK, Umetsu DT, DeKruyff RH, Freeman GJ: The TIM gene family: emerging roles in immunity and disease. Nat Rev Immunol 2003, 3:454-462.

43. Monney L, Sabatos CA, Gaglia JL, Ryu A, Waldner H, Chernova T, Manning S, Greenfield EA, Coyle AJ, Sobel RA, et al: Th1-specific cell surface protein Tim-3 regulates macrophage activation and severity of an autoimmune disease. Nature 2002, 415:536-541.

44. Sakuishi K, Jayaraman P, Behar SM, Anderson AC, Kuchroo VK: Emerging Tim-3 functions in antimicrobial and tumor immunity. Trends Immunol 2011, 32:345-349.

45. Miyanishi M, Tada K, Koike M, Uchiyama Y, Kitamura T, Nagata S: Identification of Tim4 as a phosphatidylserine receptor. Nature 2007, 450:435-439.

46. Chou FC, Shieh SJ, Sytwu HK: Attenuation of Th1 response through galectin-9 and T-cell Ig mucin 3 interaction inhibits autoimmune diabetes in NOD mice. Eur J Immunol 2009, 39:2403-2411.

47. Dardalhon V, Anderson AC, Karman J, Apetoh L, Chandwaskar R, Lee DH, Cornejo M, Nishi N, Yamauchi A, Quintana FJ, et al: Tim-3/galectin-9 pathway: regulation of Th1 immunity through promotion of CD11b + Ly6G + myeloid cells. J Immunol 2010, 185:1383-1392.

48. Vali B, Jones RB, Sakhdari A, Sheth PM, Clayton K, Yue FY, Gyenes G, Wong $D$, Klein MB, Saeed S, et al: HCV-specific T cells in HCV/HIV co-infection show elevated frequencies of dual Tim-3/PD-1 expression that correlate with liver disease progression. Eur J Immunol 2010, 40:2493-2505.

49. Sakhdari A, Mujib S, Vali B, Yue FY, MacParland S, Clayton K, Jones RB, Liu J, Lee EY, Benko $E$, et al: Tim-3 negatively regulates cytotoxicity in exhausted CD8+ T cells in HIV infection. PLoS One 2012, 7:e40146.

50. Jones RB, Ndhlovu LC, Barbour JD, Sheth PM, Jha AR, Long BR, Wong JC, Satkunarajah M, Schweneker M, Chapman JM, et al: Tim-3 expression defines a novel population of dysfunctional T cells with highly elevated frequencies in progressive HIV-1 infection. J Exp Med 2008, 205:2763-2779. 
51. Kaslow RA, Carrington M, Apple R, Park L, Munoz A, Saah AJ, Goedert JJ, Winkler C, O'Brien SJ, Rinaldo C, et al: Influence of combinations of human major histocompatibility complex genes on the course of HIV-1 infection. Nat Med 1996, 2:405-411.

52. Carrington M, Nelson GW, Martin MP, Kissner T, Vlahov D, Goedert JJ, Kaslow R, Buchbinder S, Hoots K, O'Brien SJ: HLA and HIV-1: heterozygote advantage and $B^{*} 35-\mathrm{CW}^{*} 04$ disadvantage. Science 1999, 283:1748-1752.

53. Elahi S, Dinges WL, Lejarcegui N, Laing KJ, Collier AC, Koelle DM, McElrath MJ, Horton H: Protective HIV-specific CD8+ T cells evade Treg cell suppression. Nat Med 2011, 17:989-995.

54. Migueles SA, Laborico AC, Shupert WL, Sabbaghian MS, Rabin R, Hallahan CW, Van Baarle D, Kostense S, Miedema F, McLaughlin M, et al: HIV-specific $\mathrm{CD} 8+\mathrm{T}$ cell proliferation is coupled to perforin expression and is maintained in nonprogressors. Nat Immunol 2002, 3:1061-1068.

55. Golden-Mason L, Palmer BE, Kassam N, Townshend-Bulson L, Livingston S, McMahon BJ, Castelblanco N, Kuchroo V, Gretch DR, Rosen HR: Negative immune regulator Tim-3 is overexpressed on T cells in hepatitis $C$ virus infection and its blockade rescues dysfunctional CD4+ and CD8+ T cells. J Virol 2009, 83:9122-9130.

56. McMahan RH, Golden-Mason L, Nishimura MI, McMahon BJ, Kemper M, Allen TM, Gretch DR, Rosen HR: Tim-3 expression on PD-1+ HCV-specific human CTLs is associated with viral persistence, and its blockade restores hepatocyte-directed in vitro cytotoxicity. J Clin Invest 2010, 120:4546-4557.

57. Jin HT, Anderson AC, Tan WG, West EE, Ha SJ, Araki K, Freeman GJ, Kuchroo VK, Ahmed R: Cooperation of Tim-3 and PD-1 in CD8 T-cell exhaustion during chronic viral infection. Proc Natl Acad Sci U S A 2010, 107:14733-14738.

58. Li N, Wang Y, Forbes K, Vignali KM, Heale BS, Saftig P, Hartmann D, Black RA, Rossi JJ, Blobel CP, et al: Metalloproteases regulate T-cell proliferation and effector function via LAG-3. EMBO J 2007, 26:494-504.

59. Price P, Keane N, Gray L, Lee S, Gorry PR, French MA: CXCR4 or CCR5 tropism of human immunodeficiency virus type 1 isolates does not determine the immunological milieu in patients responding to antiretroviral therapy. Viral Immunol 2006, 19:734-740.

60. Hannier S, Tournier M, Bismuth G, Triebel F: CD3/TCR complex-associated lymphocyte activation gene-3 molecules inhibit CD3/TCR signaling. $\mathrm{J}$ Immunol 1998, 161:4058-4065.

61. Okazaki T, Okazaki I, Wang J, Sugiura D, Nakaki F, Yoshida T, Kato Y, Fagarasan S, Muramatsu M, Eto T, Hioki K, Honjo T: PD-1 and LAG-3 inhibitory co-receptors act synergistically to prevent autoimmunity in mice. J Exp Med 2011, 208:395-407.

62. Huang CT, Workman CJ, Flies D, Pan X, Marson AL, Zhou G, Hipkiss EL, Ravi S, Kowalski J, Levitsky HI, Powell JD, Pardoll DM, Drake CG, Vignali DA: Role of LAG-3 in regulatory T cells. Immunity 2004, 21:503-513.

63. Blackburn SD, Shin H, Haining WN, Zou T, Workman CJ, Polley A, Betts MR, Freeman GJ, Vignali DA, Wherry EJ: Coregulation of CD8+ T cell exhaustion by multiple inhibitory receptors during chronic viral infection. Nat Immunol 2009, 10:29-37.

64. Giustiniani J, Bensussan A, Marie-Cardine A: Identification and characterization of a transmembrane isoform of CD160 (CD160-TM), a unique activating receptor selectively expressed upon human NK cell activation. J Immunol 2009, 182:63-71.

65. Richter K, Agnellini P, Oxenius A: On the role of the inhibitory receptor LAG-3 in acute and chronic LCMV infection. Int Immunol 2010, 22:13-23.

66. del Rio ML, Lucas CL, Buhler L, Rayat G, Rodriguez-Barbosa J: HVEM/LIGHT/ BTLA/CD160 cosignaling pathways as targets for immune regulation. $J$ Leukoc Biol 2010, 87:223-235.

67. Cai G, Anumanthan A, Brown JA, Greenfield EA, Zhu B, Freeman GJ: CD160 inhibits activation of human CD4+ T cells through interaction with herpesvirus entry mediator. Nat Immunol 2008, 9:176-185

68. Abecassis S, Giustiniani J, Meyer N, Schiavon V, Ortonne N, Campillo JA, Bagot M, Bensussan A: Identification of a novel CD160+ CD4+ Tlymphocyte subset in the skin: a possible role for CD160 in skin inflammation. J Invest Dermatol 2007, 127:1161-1166.

69. Sedy JR, Gavrieli M, Potter KG, Hurchla MA, Lindsley RC, Hildner K, Scheu S, Pfeffer K, Ware CF, Murphy TL, Murphy KM: B and T lymphocyte attenuator regulates $T$ cell activation through interaction with herpesvirus entry mediator. Nat Immunol 2005, 6:90-98.

70. Watanabe N, Gavrieli M, Sedy JR, Yang J, Fallarino F, Loftin SK, Hurchla MA, Zimmerman N, Sim J, Zang X, et al: BTLA is a lymphocyte inhibitory receptor with similarities to CTLA-4 and PD-1. Nat Immunol 2003, 4:670-679.

71. Li Q, Smith AJ, Schacker TW, Carlis JV, Duan L, Reilly CS, Haase AT: Microarray analysis of lymphatic tissue reveals stage-specific, gene expression signatures in HIV-1 infection. J Immunol 2009, 183:1975-1982.

72. Vendel AC, Calemine-Fenaux J, Izrael-Tomasevic A, Chauhan V, Arnott D, Eaton DL: B and T lymphocyte attenuator regulates $B$ cell receptor signaling by targeting Syk and BLNK. J Immunol 2009, 182:1509-1517.

73. Zhang Z, Xu X, Lu J, Zhang S, Gu L, Fu J, Jin L, Li H, Zhao M, Zhang J, et al: $B$ and $T$ lymphocyte attenuator down-regulation by HIV-1 depends on type I interferon and contributes to T-cell hyperactivation. J Infect Dis 2011, 203:1668-1678.

74. Xu XS, Zhang Z, Gu LL, Wang FS: BTLA Characterization and its association with disease progression in patients with chronic HIV-1 infection. Xi Bao Yu Fen Zi Mian Yi Xue Za Zhi 2009, 25:1158-1160.

75. Mathew SO, Vaidya SV, Kim JR, Mathew PA: Human natural killer cell receptor 2B4 (CD244) down-regulates its own expression by reduced promoter activity at an Ets element. Biochem Biophys Res Commun 2007, 355:483-487.

76. Schlaphoff V, Lunemann S, Suneetha PV, Jaroszewicz J, Grabowski J, Dietz J, Helfritz F, Bektas H, Sarrazin C, Manns MP, et al: Dual function of the NK cell receptor 2B4 (CD244) in the regulation of HCV-specific CD8+ T cells. PLOS Pathog 2011, 7:e1002045.

77. Bengsch B, Seigel B, Ruhl M, Timm J, Kuntz M, Blum HE, Pircher H, Thimme R: Coexpression of PD-1, 2B4, CD160 and KLRG1 on exhausted HCVspecific CD8+ T cells is linked to antigen recognition and $T$ cell differentiation. PLOS Pathog 2010, 6:e1000947.

78. Kumar V, McNerney ME: A new self: MHC-class-I-independent naturalkiller-cell self-tolerance. Nat Rev Immunol 2005, 5:363-374.

79. Ostrowski SR, Ullum H, Pedersen BK, Gerstoft J, Katzenstein TL: 2B4 expression on natural killer cells increases in HIV-1 infected patients followed prospectively during highly active antiretroviral therapy. Clin Exp Immunol 2005, 141:526-533.

80. Peritt $D$, Sesok-Pizzini DA, Schretzenmair R, Macgregor RR, Valiante NM, Tu $X$, Trinchieri G, Kamoun M: C1.7 antigen expression on CD8+ T cells is activation dependent: increased proportion of C1.7 + CD8+ T cells in HIV-1-infected patients with progressing disease. J Immunol 1999, 162:7563-7568.

81. Aldy KN, Horton NC, Mathew PA, Mathew SO: 2B4+ CD8+ T cells play an inhibitory role against constrained HIV epitopes. Biochem Biophys Res Commun 2011, 405:503-507.

82. Yamamoto T, Price DA, Casazza JP, Ferrari G, Nason M, Chattopadhyay PK, Roederer M, Gostick E, Katsikis PD, Douek DC, et al: Surface expression patterns of negative regulatory molecules identify determinants of virusspecific CD8+ T-cell exhaustion in HIV infection. Blood 2011, 117:4805-4815.

83. McIntire RH, Sifers T, Platt JS, Ganacias KG, Langat DK, Hunt JS: Novel HLAG-binding leukocyte immunoglobulin-like receptor (LILR) expression patterns in human placentas and umbilical cords. Placenta 2008 29:631-638.

84. Anderson KJ, Allen RL: Regulation of T-cell immunity by leucocyte immunoglobulin-like receptors: innate immune receptors for self on antigen-presenting cells. Immunology 2009, 127:8-17.

85. Lichterfeld M, Kavanagh DG, Williams KL, Moza B, Mui SK, Miura T, Sivamurthy R, Allgaier R, Pereyra F, Trocha A, et al: A viral CTL escape mutation leading to immunoglobulin-like transcript 4-mediated functional inhibition of myelomonocytic cells. J Exp Med 2007, 204:2813-2824.

86. O'Connor GM, Holmes A, Mulcahy F, Gardiner CM: Natural Killer cells from long-term non-progressor HIV patients are characterized by altered phenotype and function. Clin Immunol 2007, 124:277-283.

87. Anfossi N, Doisne JM, Peyrat MA, Ugolini S, Bonnaud O, Bossy D, Pitard V, Merville P, Moreau JF, Delfraissy JF, et al: Coordinated expression of Ig-like inhibitory $\mathrm{MHC}$ class I receptors and acquisition of cytotoxic function in human CD8+ T cells. J Immunol 2004, 173:7223-7229.

88. Vlad G, Piazza F, Colovai A, Cortesini R, Della Pietra F, Suciu-Foca N, Manavalan JS: Interleukin-10 induces the upregulation of the inhibitory receptor ILT4 in monocytes from HIV positive individuals. Hum Immunol 2003, 64:483-489.

89. Huang J, Burke PS, Cung TD, Pereyra F, Toth I, Walker BD, Borges L, Lichterfeld M, Yu XG: Leukocyte immunoglobulin-like receptors maintain 
unique antigen-presenting properties of circulating myeloid dendritic cells in HIV-1-infected elite controllers. J Virol 2010, 84:9463-9471.

90. Herbeuval JP, Grivel JC, Boasso A, Hardy AW, Chougnet C, Dolan MJ, Yagita H, Lifson JD, Shearer GM: CD4+ T-cell death induced by infectious and noninfectious HIV-1: role of type 1 interferon-dependent, TRAIL/DR5mediated apoptosis. Blood 2005, 106:3524-3531.

91. Vidalain PO, Azocar O, Lamouille B, Astier A, Rabourdin-Combe C, ServetDelprat C: Measles virus induces functional TRAIL production by human dendritic cells. J Virol 2000, 74:556-559.

92. Lunemann JD, Waiczies S, Ehrlich S, Wendling U, Seeger B, Kamradt T, Zipp F: Death ligand TRAIL induces no apoptosis but inhibits activation of human (auto)antigen-specific T cells. J Immunol 2002, 168:4881-4888.

93. Pan G, O'Rourke K, Chinnaiyan AM, Gentz R, Ebner R, Ni J, Dixit VM: The receptor for the cytotoxic ligand TRAIL. Science 1997, 276:111-113.

94. Chaudhary PM, Eby M, Jasmin A, Bookwalter A, Murray J, Hood L: Death receptor 5, a new member of the TNFR family, and DR4 induce FADDdependent apoptosis and activate the NF-kappaB pathway. Immunity 1997, 7:821-830

95. Voehringer D, Blaser C, Brawand P, Raulet DH, Hanke T, Pircher H: Viral infections induce abundant numbers of senescent CD8 T cells. J Immunol 2001, 167:4838-4843.

96. Thimme R, Appay V, Koschella M, Panther E, Roth E, Hislop AD, Rickinson $A B$, Rowland-Jones SL, Blum HE, Pircher H: Increased expression of the NK cell receptor KLRG1 by virus-specific CD8 T cells during persistent antigen stimulation. J Virol 2005, 79:12112-12116.

97. Gründemann C, Schwartzkopff S, Koschella M, Schweier O, Peters C, Voehringer D, Pircher $H$ : The NK receptor KLRG1 is dispensable for virusinduced NK and CD8+ T-cell differentiation and function in vivo. Eur J Immunol 2010, 40:1303-1314.

98. Martins G, Calame K: Regulation and functions of Blimp-1 in T and B lymphocytes. Annu Rev Immunol 2008, 26:133-169.

99. Rutishauser RL, Martins GA, Kalachikov S, Chandele A, Parish IA, Meffre E, Jacob J, Calame K, Kaech SM: Transcriptional repressor BLIMP-1 promotes CD8(+) T cell terminal differentiation and represses the acquisition of central memory T cell properties. Immunity 2009, 31:296-308.

100. Kallies A, Hawkins ED, Belz GT, Metcalf D, Hommel M, Corcoran LM, Hodgkin PD, Nutt SL: Transcriptional repressor BLIMP-1 is essential for T cell homeostasis and self-tolerance. Nat Immunol 2006, 7:466-474.

101. Zheng Y, Josefowicz SZ, Kas A, Chu TT, Gavin MA, Rudensky AY: Genomewide analysis of FoxP3 target genes in developing and mature regulatory T cells. Nature 2007, 445:936-940.

102. Ohkura N, Sakaguchi S: Maturation of effector regulatory T cells. Nat Immunol 2011, 12:283-284.

103. Shin H, Blackburn SD, Intlekofer AM, Kao C, Angelosanto JM, Reiner SL, Wherry EJ: A role for the transcriptional repressor Blimp-1 in CD8(+) T cell exhaustion during chronic viral infection. Immunity 2009, 31:309-320.

104. Seddiki N, Phetsouphanh C, Swaminathan S, Xu Y, Rao S, Li J, Sutcliffe EL, Denyer G, Finlayson R, Gelgor L, Cooper DA, Zaunders J, Kelleher AD: The microRNA-9/B-lymphocyte-induced maturation protein-1/IL-2 axis is differentially regulated in progressive HIV infection. Eur J Immunol 2013, 43:510-520

105. Thaventhiran JE, Fearon DT: Control of HIV infection: Escape from the shadow of Blimp-1. Eur J Immunol 2013, 43:323-326.

106. Nigam P, Velu V, Kannanganat S, Chennareddi L, Kwa S, Siddiqui M, Amara RR: Expansion of FOXP3+ CD8 T cells with suppressive potential in colorectal mucosa following a pathogenic simian immunodeficiency virus infection correlates with diminished antiviral T cell response and viral control. J Immunol 2010, 184:1690-1701.

107. Nilsson J, Boasso A, Velilla PA, Zhang R, Vaccari M, Franchini G, Shearer GM Andersson J, Chougnet C: HIV-1-driven regulatory T-cell accumulation in lymphoid tissues is associated with disease progression in HIV/AIDS. Blood 2006, 108:3808-3817.

108. Andersson J, Boasso A, Nilsson J, Zhang R, Shire NJ, Lindback S, Shearer GM, Chougnet CA: The prevalence of regulatory $T$ cells in lymphoid tissue is correlated with viral load in HIV-infected patients. J Immunol 2005, 174:3143-3147.

109. Aandahl EM, Michaelsson J, Moretto WJ, Hecht FM, Nixon DF: Human CD4+ $\mathrm{CD} 25+$ regulatory $\mathrm{T}$ cells control T-cell responses to human immunodeficiency virus and cytomegalovirus antigens. J Virol 2004, 78:2454-2459.
110. Kinter AL, Hennessey M, Bell A, Kern S, Lin Y, Daucher M, Planta M, McGlaughlin M, Jackson R, Ziegler SF, Fauci AS: CD25(+)CD4(+) regulatory $T$ cells from the peripheral blood of asymptomatic HIV-infected individuals regulate CD4(+) and CD8(+) HIV-specific T cell immune responses in vitro and are associated with favorable clinical markers of disease status. J Exp Med 2004, 200:331-343.

111. Birebent B, Lorho R, Lechartier H, de Guibert S, Alizadeh M, Vu N, Beauplet A, Robillard N, Semana G: Suppressive properties of human CD4 + CD25+ regulatory $\mathrm{T}$ cells are dependent on CTLA-4 expression. Eur J Immunol 2004, 34:3485-3496.

112. Loxton A, Roberts T, Black G, Walzl G: P16-01. Regulatory T-cells and high levels of FOXP3 mRNA leads to decreased immune responses in HIV-TB co-infection. Retrovirology 2009, 6:P230.

113. Wu Y, Borde M, Heissmeyer V, Feuerer M, Lapan AD, Stroud JC, Bates DL, Guo L, Han A, Ziegler SF, et al: FOXP3 controls regulatory $T$ cell function through cooperation with NFAT. Cell 2006, 126:375-387.

114. Hersperger AR, Martin JN, Shin LY, Sheth PM, Kovacs CM, Cosma GL, Makedonas G, Pereyra F, Walker BD, Kaul R, et al: Increased HIV-specific CD8+ T-cell cytotoxic potential in HIV elite controllers is associated with T-bet expression. Blood 2011, 117:3799-3808.

115. Townsend MJ, Weinmann AS, Matsuda JL, Salomon R, Farnham PJ, Biron CA, Gapin L, Glimcher LH: T-bet regulates the terminal maturation and homeostasis of NK and Valpha14i NKT cells. Immunity 2004, 20:477-494.

116. Intlekofer AM, Takemoto N, Wherry EJ, Longworth SA, Northrup JT, Palanivel VR, Mullen AC, Gasink CR, Kaech SM, Miller JD, et al: Effector and memory CD8+ T cell fate coupled by T-bet and eomesodermin. Nat Immunol 2005, 6:1236-1244.

117. Kao C, Oestreich KJ, Paley MA, Crawford A, Angelosanto JM, Ali MA, Intlekofer AM, Boss JM, Reiner SL, Weinmann AS, Wherry EJ: Transcription factor T-bet represses expression of the inhibitory receptor PD-1 and sustains virus-specific CD8+ T cell responses during chronic infection. Nat Immunol 2011, 12:663-671.

118. Oestreich KJ, Weinmann AS: T-bet employs diverse regulatory mechanisms to repress transcription. Trends Immunol 2012, 33:78-83.

119. Kallies A, Carotta S, Huntington ND, Bernard NJ, Tarlinton DM, Smyth MJ, Nutt SL: A role for Blimp1 in the transcriptional network controlling natural killer cell maturation. Blood 2011, 117:1869-1879.

120. Joshi NS, Cui W, Chandele A, Lee HK, Urso DR, Hagman J, Gapin L, Kaech SM: Inflammation directs memory precursor and short-lived effector CD8(+) T cell fates via the graded expression of T-bet transcription factor. Immunity 2007, 27:281-295.

121. Thaventhiran JE, Hoffmann A, Magiera L, de la Roche M, Lingel H, BrunnerWeinzierl M, Fearon DT: Activation of the Hippo pathway by CTLA-4 regulates the expression of BLIMP-1 in the CD8+ T cell. Proc Natl Acad SCi U S A 2012, 109:2223-2229.

122. Williams KL, Nanda I, Lyons GE, Kuo CT, Schmid M, Leiden JM, Kaplan MH, Taparowsky EJ: Characterization of murine BATF: a negative regulator of activator protein-1 activity in the thymus. Eur J Immunol 2001 31:1620-1627.

123. Wiley SR, Schooley K, Smolak PJ, Din WS, Huang CP, Nicholl JK, Sutherland GR, Smith TD, Rauch C, Smith CA, et al: Identification and characterization of a new member of the TNF family that induces apoptosis. Immunity 1995, 3:673-682

124. Kuroda S, Yamazaki M, Abe M, Sakimura K, Takayanagi H, Iwai Y: Basic leucine zipper transcription factor, ATF-like (BATF) regulates epigenetically and energetically effector CD8 T-cell differentiation via Sirt1 expression. Proc Natl Acad Sci U S A 2011, 108:14885-14889.

125. Schraml BU, Hildner K, Ise W, Lee WL, Smith WA, Solomon B, Sahota G, Sim J, Mukasa R, Cemerski S, Hatton RD, Stormo GD, Weaver $\subset T$, Russell JH, Murphy TL, Murphy KM: The AP-1 transcription factor Batf controls T(H)17 differentiation. Nature 2009, 460:405-409.

126. Lim CP, Cao X: Regulation of Stat3 activation by MEK kinase 1. J Biol Chem 2001, 276:21004-21011.

127. Zarubin T, Han J: Activation and signaling of the p38 MAP kinase pathway. Cell Res 2005, 15:11-18.

128. Gibson HM, Hedgcock CJ, Aufiero BM, Wilson AJ, Hafner MS, Tsokos GC, Wong HK: Induction of the CTLA-4 gene in human lymphocytes is dependent on NFAT binding the proximal promoter. J Immunol 2007, 179:3831-3840.

129. Agnellini P, Wolint $P$, Rehr M, Cahenzli J, Karrer U, Oxenius A: Impaired NFAT nuclear translocation results in split exhaustion of virus-specific 
CD8+ T cell functions during chronic viral infection. Proc Natl Acad Sci U S A 2007, 104:4565-4570.

130. Migueles SA, Osborne CM, Royce C, Compton AA, Joshi RP, Weeks KA, Rood JE, Berkley AM, Sacha JB, Cogliano-Shutta NA, et al: Lytic granule loading of CD8+ T cells is required for HIV-infected cell elimination associated with immune control. Immunity 2008, 29:1009-1021.

131. Hsiao HW, Liu WH, Wang CJ, Lo YH, Wu YH, Jiang ST, Lai MZ: Deltex1 is a target of the transcription factor NFAT that promotes T cell anergy. Immunity 2009, 31:72-83.

132. Sakoe Y, Sakoe K, Kirito K, Ozawa K, Komatsu N: FOXO3A as a key molecule for all-trans retinoic acid-induced granulocytic differentiation and apoptosis in acute promyelocytic leukemia. Blood 2010, 115:3787-3795.

133. Dabrowska A, Kim N, Aldovini A: Tat-induced FOXO3a is a key mediator of apoptosis in HIV-1-infected human CD4+ T lymphocytes. J Immuno/ 2008, 181:8460-8477.

134. van Grevenynghe J, Cubas RA, Noto A, DaFonseca S, He Z, Peretz Y, FilaliMouhim A, Dupuy FP, Procopio FA, Chomont N, Balderas RS, Said EA Boulassel MR, Tremblay CL, Routy JP, Sékaly RP, Haddad EK: Loss of memory $\mathrm{B}$ cells during chronic HIV infection is driven by Foxo3a- and TRAIL-mediated apoptosis. J Clin Invest 2011, 121:3877-3888.

135. Kleinsteuber K, Heesch K, Schattling S, Sander-Juelch C, Mock U, Riecken K, Fehse B, Fleischer B, Jacobsen M: SOCS3 promotes interleukin-17 expression of human T cells. Blood 2012, 120:4374-4382.

136. Pellegrini M, Calzascia T, Toe JG, Preston SP, Lin AE, Elford AR, Shahinian A, Lang PA, Lang KS, Morre M, et al: IL-7 engages multiple mechanisms to overcome chronic viral infection and limit organ pathology. Cell 2011 144:601-613.

137. Dong J, Feldmann G, Huang J, Wu S, Zhang N, Comerford SA, Gayyed MF, Anders RA, Maitra A, Pan D: Elucidation of a universal size-control mechanism in Drosophila and mammals. Cell 2007, 130:1120-1133.

138. Moffett JR, Namboodiri MA: Tryptophan and the immune response. Immunol Cell Biol 2003, 81:247-265.

139. Mellor AL, Munn DH: IDO expression by dendritic cells: tolerance and tryptophan catabolism. Nat Rev Immunol 2004, 4:762-774.

140. Baban B, Hansen AM, Chandler PR, Manlapat A, Bingaman A, Kahler DJ, Munn DH, Mellor AL: A minor population of splenic dendritic cells expressing CD19 mediates IDO-dependent T cell suppression via type I IFN signaling following B7 ligation. Int Immunol 2005, 17:909-919.

141. Fallarino F, Grohmann U, Hwang KW, Orabona C, Vacca C, Bianchi R, Belladonna ML, Fioretti MC, Alegre ML, Puccetti P: Modulation of tryptophan catabolism by regulatory T cells. Nat Immunol 2003, 4:1206-1212.

142. Mulley WR, Nikolic-Paterson DJ: Indoleamine 2,3-dioxygenase in transplantation. Nephrology (Carlton) 2008, 13:204-211

143. Werner ER, Fuchs D, Hausen A, Jaeger H, Reibnegger G, Werner-Felmayer G, Dierich MP, Wachter H: Tryptophan degradation in patients infected by human immunodeficiency virus. Biol Chem Hoppe Seyler 1988, 369:337-340.

144. Boasso A, Shearer GM: How does indoleamine 2,3-dioxygenase contribute to HIV-mediated immune dysregulation. Curr Drug Metab 2007, 8:217-223.

145. Pallotta MT, Orabona C, Volpi C, Vacca C, Belladonna ML, Bianchi R, Servillo G, Brunacci C, Calvitti M, Bicciato S, et al: Indoleamine 2,3-dioxygenase is a signaling protein in long-term tolerance by dendritic cells. Nat Immunol 2011, 12:870-878

146. Moore KW, de Waal MR, Coffman RL, O'Garra A: Interleukin-10 and the interleukin-10 receptor. Annu Rev Immunol 2001, 19:683-765.

147. Pestka S, Krause CD, Sarkar D, Walter MR, Shi Y, Fisher PB: Interleukin-10 and related cytokines and receptors. Annu Rev Immunol 2004, 22:929-979.

148. Jin HT, Jeong YH, Park HJ, Ha SJ: Mechanism of T cell exhaustion in a chronic environment. BMB Rep 2011, 44:217-231.

149. Brooks DG, Ha SJ, Elsaesser H, Sharpe AH, Freeman GJ, Oldstone MB: IL-10 and PD-L1 operate through distinct pathways to suppress T-cell activity during persistent viral infection. Proc Natl Acad Sci U S A 2008, 105:20428-20433.

150. Said EA, Dupuy FP, Trautmann L, Zhang Y, Shi Y, El-Far M, Hill BJ, Noto A, Ancuta P, Peretz Y, Fonseca SG, Van Grevenynghe J, Boulassel MR, Bruneau J, Shoukry NH, Routy JP, Douek DC, Haddad EK, Sekaly RP: Programmed death-1-induced interleukin-10 production by monocytes impairs CD4+ T cell activation during HIV infection. Nat Med 2010, 16:452-459.

151. Stylianou E, Aukrust P, Kvale D, Muller F, Froland SS: IL-10 in HIV infection: increasing serum IL-10 levels with disease progression-down-regulatory effect of potent anti-retroviral therapy. Clin Exp Immunol 1999 116:115-120.

152. Clerici M, Wynn TA, Berzofsky JA, Blatt SP, Hendrix CW, Sher A, Coffman RL, Shearer GM: Role of interleukin-10 in T helper cell dysfunction in asymptomatic individuals infected with the human immunodeficiency virus. J Clin Invest 1994, 93:768-775.

153. Brockman MA, Kwon DS, Tighe DP, Pavlik DF, Rosato PC, Sela J, Porichis F, Le Gall S, Waring MT, Moss K, et al: IL-10 is up-regulated in multiple cell types during viremic HIV infection and reversibly inhibits virus-specific $T$ cells. Blood 2009, 114:346-356.

154. Li MO, Sanjabi S, Flavell RA: Transforming growth factor- $\beta$ controls development, homeostasis, and tolerance of $\mathrm{T}$ cells by regulatory $\mathrm{T}$ celldependent and -independent mechanisms. Immunity 2006, 25:455-471.

155. Elrefaei M, Burke CM, Baker CA, Jones NG, Bousheri S, Bangsberg DR, Cao H: TGF- $\beta$ and IL-10 production by HIV-specific CD8+ T cells is regulated by CTLA-4 signaling on CD4+ T cells. PLoS One 2009, 4:e8194.

156. Elrefaei M, Burke CM, Baker CAR, Jones NG, Bousheri S, Bangsberg DR, Cao $\mathrm{H}$ : HIV-specific TGF- $\beta$-positive $C D 4^{+}$T cells do not express regulatory surface markers and are regulated by CTLA-4. AIDS Res Hum Retroviruses 2010, 26:329-337.

157. Garidou L, Heydari S, Gossa S, McGavern DB: Therapeutic blockade of transforming growth factor beta fails to promote clearance of a persistent viral infection. J Virol 2012, 86:7060-7071.

158. Boettler T, Cheng Y, Ehrhardt $K$, von Herrath M: TGF- $\beta$ blockade does not improve control of an established persistent viral infection. Viral Immunol 2012, 25:232-238.

159. Khaitan A, Unutmaz D: Revisiting immune exhaustion during HIV infection. Curr HIV/AIDS Rep 2011, 8:4-11.

doi:10.1186/1742-4690-10-31

Cite this article as: Larsson et al:: Molecular signatures of T-cell inhibition in HIV-1 infection. Retrovirology 2013 10:31.

\section{Submit your next manuscript to BioMed Central and take full advantage of:}

- Convenient online submission

- Thorough peer review

- No space constraints or color figure charges

- Immediate publication on acceptance

- Inclusion in PubMed, CAS, Scopus and Google Scholar

- Research which is freely available for redistribution 